Katy Long

\section{Office for National Statistics}

\section{SUMMARY}

This article presents current price labour productivity estimates using published data from the Annual Business Inquiry $(A B I)$. The article updates the work of Goodridge (2007) and Daffin and Lau (2002) in presenting estimates for the years 2006 and 2007. A new development presented in this article are constant price labour productivity measures which have been formulated using Producer Price Indices (PPI) and the experimental Services Producer Price Indices (SPPI) to deflate output. These enable a more accurate analysis of industry labour productivity trends over time. It is found that capital intensive industries generally exhibit both higher levels and growth in labour productivity over the sample period.

\title{
Labour productivity measures from the ABI: 1998 to 2007
}

T he Annual Business Inquiry (ABI) was introduced by the Office for National Statistics (ONS) between 1998 and 2001. The ABI brings together employment (ABI/1) and financial/ turnover $(\mathrm{ABI} / 2)$ data into one survey where previously it was collected using the Annual Employment Survey, Annual Census of Production, Annual Census of Construction and Distribution and Service Inquiries ${ }^{1}$. Although there has since been some divergence between the two parts of the ABI (see Gough 2009), so care should be taken in interpreting changes over time, the development of the ABI has allowed for the aggregates to be collected using a reasonably common methodology, resulting in greater consistency between input and output data. Coherent labour productivity estimates can therefore be produced at a detailed level.

The ONS Productivity Statistical Bulletin contains quarterly labour productivity estimates for the whole economy, broken down into Total production industries, Total manufacturing, Agriculture, forestry and fisheries, Total services, and a number of selected service industries. These estimates are based on chainedvolume measures of gross value added (GVA). Breakdowns for subsections of manufacturing are also presented. Additionally, the Statistical Bulletin contains estimates for the market sector on an experimental basis. The Productivity Statistical Bulletin and associated data sets can be found at www.statistics.gov.uk/ statbase/product.asp?vlnk=7476.
Labour productivity estimates in the Productivity Statistical Bulletin differ from those presented in this article in the following ways:

- the Statistical Bulletin estimates use an output measure from the National Accounts. The employment measure mainly comes from the quarterly Short Term Employment Survey which are benchmarked to annual ABI data. These data are then joined with estimates of self-employment, government supported trainees and HM forces for the appropriate industries before the totals are constrained to the Labour Force Survey whole economy figures. This results in reduced consistency between the output and input data, largely arising from the coherence and balancing adjustments made to the National Accounts. In contrast, the estimates presented in this article are based on ABI data that have not undergone National Accounts adjustments

- additionally, the estimates presented in the Statistical Bulletin are in constant prices, whereas those presented here are in current prices. While the current price format does not allow for the analysis of trends in productivity over time, it does facilitate comparisons in the levels of productivity across industries for a given reference year

- most importantly, the estimates presented in this article contain a more detailed industry breakdown according 
to the Standard Industrial Classification 2003 (SIC 2003), than is available in the Statistical Bulletin

The published ABI data, on which these labour productivity estimates are based, can be found at www.statistics.gov.uk/abi. National, rather than regional, employment estimates from $\mathrm{AB} 1 / 1$ have been used as these are provided on a consistent basis with $\mathrm{AB} 1 / 2$ data. Finalised data are available 18 months after the end of a given reference year. The most recent finalised data available relate to the 2007 reference year. It is important to note that $\mathrm{ABI}$ revisions arising from quality and omissions issues are only taken back two years. This means that the $\mathrm{ABI}$ is only consistent on a rolling basis for the reference years 2007 and 2006 which should be taken into account when interpreting the time series of estimates. Approximate GVA per job estimates are not available prior to 1998 . This is because although approximate GVA data are available from the ABI from 1995 onwards, an employment measure consistent with this is not available until $1998^{2}$.

\section{Quality issues}

The output measure used in the production of these results is 'approximate' GVA in basic prices. This differs from the GVA estimates published in the Input-Output Supply and Use Tables which are compiled in accordance with the 1995 European System of Accounts (ESA 95). The primary differences between the two are that the approximate GVA omits adjustments for taxes and subsidies or income received in kind. Additionally the GVA estimates contained in the Supply-Use framework are subject to conceptual, quality and coherence adjustments. These are described in greater detail in Box 1.

For certain industries, the ABI estimate of approximate GVA per job is judged to be of low quality and in these cases the measure has been withdrawn. This applies for the following industries:

- Agriculture, hunting and related service activities (SIC 01); Forestry, logging and related service activities (SIC 02); and Fishing (SIC 05). These measures have primarily been withdrawn due to the prevalence of grants and subsidies in these industries. Additionally, data for these divisions has only been collected since 2000/2001, and as such the data are relatively new

- Air transport (SIC 62). For this division the ABI series is of poor quality. Changes in time tend to reflect improvements in measurement rather than real economic change

- Financial intermediation (SIC 65-67); and Public administration, defence and compulsory social security (SIC 75). In the first case financial data is not currently published and in the second case it is not collected by the ABI

- Real estate activities (SIC 70). The approximate GVA measure excludes capital expenditure, and as such, is not a representative measure due to the nature of the real estate industry. For example, there will typically be high levels of capital expenditure and low levels of turnover during the early stages of a project's development and vice-versa in the latter stages

- Research and development (SIC

73) and subdivisions of Activities of membership organisations( SIC 91.1 and 91.3). For these industries, much of their activity takes place within the nonmarket sector. Since government grants are excluded from the approximate GVA measures the estimates for these divisions have been withdrawn
- Education (SIC 80) and Health and social work (SIC 85). The exclusion of government grants from the data often results in negative values of GVA for these sectors. Furthermore, since the $\mathrm{ABI}$ is not distributed to public bodies the estimates are not considered representative of these divisions

For the following industries, although labour productivity estimates are published, users should exercise caution when interpreting the results:

- Manufacture of beverages (SIC 15.9); Manufacture of tobacco products (SIC 16); and Wholesale of food, beverages and tobacco (SIC 51.3). Due to the desire of firms to minimise duty payments, the timing of the release of goods from bonded warehouses is subject to considerable variation. This results in volatile estimates of GVA for these industries

- Manufacture of refined petroleum products (SIC 23.3). Firms in this division tend to change the time at which they report their duty payments. The result is that for some years payments may appear in wholesale and for others they may appear in refining. Despite ONS attempts to minimise the differences in reported duty payments, the GVA estimates are subject to considerable volatility

Due to issues with data quality and volatility the following SIC(2003) divisions have been aggregated as follows:

- Extraction of crude petroleum and natural gas (SIC 1110) and Service activities incidental to oil and gas extraction excluding surveying (SIC 1120) have been aggregated to SIC 1100 level

\section{Box 1}

\section{National Accounts adjustments \\ Conceptual adjustments}

These are the adjustments required to translate data sources into National Accounts concepts. These include adjustments to allow for undeclared income in the income measure and adjustments to retail sales to exclude spending by businesses in shops in the household final consumption expenditure measure. These well-established adjustments take place as part of the national accounts compiling process and are made prior to the balancing exercise which takes place under the Supply-Use framework.

\section{Quality adjustments}

These adjustments take place after conceptual adjustments are made and are intended to correct for known biases and discontinuities in the source data. Such adjustments often occur as a result of revisions analysis, for example, correction for systematic under reporting of a component.

\section{Coherence adjustments}

These adjustments are applied at the final stage of the balancing process, once the data has been scrutinised and validated against other data sources. The adjustments, which are carried out at a detailed industry and product level, are used to secure a balance between supply and demand, outputs and inputs and reflect the known relative weaknesses in the accounts.

For further information on the National Accounts adjustments see Penneck and Mahajan (1999). 
- Manufacture of pulp ( SIC 2111) and Manufacture of paper and paperboard (SIC 2112) have been aggregated to SIC 2110 level

- Agents involved in the sale of agricultural raw materials, live animals, textile raw materials and semi finished goods to Agents involved in the sale of a variety of goods (SIC 5111 to 5119) have been aggregated to SIC 5100 level

- Wholesale of grain, seeds and animal feeds to Wholesale of un-manufactured tobacco (SIC 5121 to 5125) have been aggregated to SIC 5120 level

- Wholesale of tobacco products to Wholesale of coffee, tea, cocoa and spices (SIC 5135 to 5137) have been aggregated to SIC 5135-5137 level.

- Repair of boots, shoes and other articles of leather to Repair not elsewhere Classified (SIC 5271 to 5274 have been aggregated to SIC 5270 level

- Hotels and motels, with restaurants (licensed) (SIC 5511) and Hotels and motels, with restaurants (unlicensed) (SIC 5512) have been aggregated to 5510 level

- Data processing (SIC 7230) and Database activities (SIC 7240) have been aggregated to SIC 72.3/72.4 level.

In addition, some approximate GVA per worker estimates for SIC(2003) divisions at the four-digit level have been suppressed, due to their disclosive nature. This is also true of those divisions where employment is less than 500. However, data for these industries are still included within broader aggregates.

\section{Employment}

Labour productivity estimates presented in this article use ABI year-average employment as their input measure. This variable is derived by adjusting the $\mathrm{ABI}$ point-in-time employment estimate using employment measures from the quarterly STES data. This removes elements of seasonality that may be present from using the point-in-time $\mathrm{ABI}$ estimates which refer to the month of December. However, it also results in the loss of some consistency between input and output data. The methodology used to calculate this year average employment measure is outlined in Box 2. It should be taken into account that the labour productivity estimates are based on output per worker, as opposed to output per hour worked. This will result in underestimates of productivity for those sectors in which part time work is more prevalent and overestimates for those industries in which part time work is less prevalent.

\section{Analysis}

In contrast to the estimates contained in the Productivity Statistical Bulletin, the results presented in this article allow for a much more detailed breakdown by industry and service subdivisions. This is particularly true of the service sector, for which the Productivity Statistical Bulletin only contains breakdowns by Distribution, hotels and restaurants; Transport, storage and communication; and Business services and finance. Note, however, that sections J and L (Financial intermediation and Public administration and defence respectively) are not covered by the $\mathrm{ABI}$, and the data for sections $\mathrm{M}$ and $\mathrm{N}$ (Education and Health and social work respectively) are not considered representative of their industries.

An inspection of the broad sector level results, presented in Table $\mathbf{1}$, show that labour productivity in the service sectors is well below that of the production sectors (excluding SIC 2003 sections A,B,J,L,M,N and divisions 62 and 70 (section $\mathrm{K})$ ).
This empirical phenomenon has been a pervasive feature of productivity estimates and is often attributed to the Baumol Effect, (Baumol 1967). Also known as Baumol's Disease, this is the theory that lower levels (and growth rates) of labour productivity in the service sector are due to higher levels of labour intensity. That is to say that service industries typically use a higher proportion of labour relative to capital inputs in their production process. This relatively high labour intensity means that service industries tend to be worse placed to benefit from advances in technology.

However, these estimates are expressed in current prices and as such do not allow for a consistent assessment of growth in labour productivity. Deflating the manufacturing sector estimates of GVA by the output Producer Prices Index (PPI), and selected service divisions by the relevant experimental Services Producer Prices Index (SPPI) series, allows us to broadly gauge the growth in labour productivity over the period. It must be emphasised that only broad trends in time can be inferred from this deflated data since, as previously mentioned, the revisions to the $\mathrm{ABI}$ arising from quality issues or omissions are only taken back two years. Furthermore the coverage of the deflators used for the selected service sector divisions do not perfectly match.

Figure 1 plots the labour productivity estimates for the manufacturing sector and an aggregation of selected service sector divisions, ${ }^{3}$ for which the output measures have been deflated to constant 2005 prices. In line with the predictions of Baumol's theory, growth over the entire period in the service divisions' productivity is below that of the manufacturing sector. Specifically, using 1998 as the base year, the index of labour productivity for the service industries in 2007 is 123 compared

\section{Box 2}

\section{Calculation of $A B I$ year-average employment}

$A B$ year-average employment $=A B$ year average employees + $A B I$ working proprietors $+A B I$ unpaid workers

$A B I$ year-average employees is calculated by taking the $A B I$ point-in-time data at the reporting unit level and applying local unit level factors from the STES.

As an example, the STES factor for 2005 would be calculated as below:

(STES December $2004+(3 \times$ STES March 2005) + (3 x STES June 2005) + (3 x STES September 2005) + ( $2 \times$ STES December 2005) $)$ $/ 12 \times$ STES December 2005
The calculation is performed separately for each of the male/ female/full-time/part-time splits by STES SIC section building blocks. They are then applied to each of the December returns before grossing to generate year-average employment levels.

The $A B I$ unpaid workers and $A B I$ working proprietors series cannot be adjusted for seasonality since there is no data available on them from the STES. Although the IDBR (Inter Departmental Business Register) and Labour Force Survey (LFS) contain data on working proprietors and unpaid workers, respectively, it is not considered reliable enough to adjust $A B I$ data at a detailed level. 
Table 1

$A B I$ 'approximate GVA per job' in current prices

\begin{tabular}{llrrrrrrrrrr}
$\mathbf{E}$ thousands \\
\hline SIC03 section & Description & 1998 & $\mathbf{1 9 9 9}$ & $\mathbf{2 0 0 0}$ & $\mathbf{2 0 0 1}$ & $\mathbf{2 0 0 2}$ & $\mathbf{2 0 0 3}$ & $\mathbf{2 0 0 4}$ & $\mathbf{2 0 0 5}$ & $\mathbf{2 0 0 6}$ & $\mathbf{2 0 0 7}$ \\
\hline C-O & All sectors covered by the ABI & 28.7 & 30.1 & 31.1 & 32.1 & 32.8 & 34.0 & 36.1 & 38.0 & 40.6 & 42.8 \\
C-E & Production sector & 38.5 & 40.4 & 42.7 & 43.7 & 46.5 & 47.2 & 51.7 & 57.5 & 60.3 & 64.3 \\
D & Manufacturing & 33.9 & 35.2 & 35.9 & 36.6 & 39.3 & 40.2 & 43.7 & 44.6 & 48.2 & 51.4 \\
F & Construction & 27.2 & 29.8 & 31.6 & 35.9 & 36.7 & 40.0 & 41.9 & 45.4 & 48.5 & 52.2 \\
G-O & Service sector & 25.2 & 26.5 & 27.2 & 28.1 & 28.6 & 29.8 & 31.4 & 33.1 & 35.0 & 36.8 \\
\hline
\end{tabular}

Note:

Source: Office for National Statistics

1 Excludes SIC03 sections $A, B, J, L, M, N$ and divisions 62 and 70 (section $K$ ).

\section{Figure 1}

\section{ABI labour productivity estimates using GVA at constant prices}

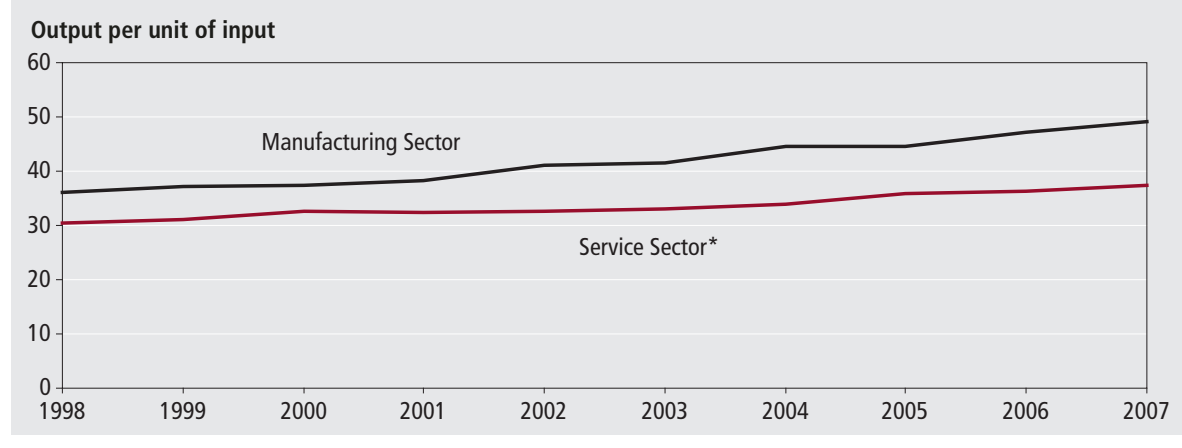

Note:

Source: Office for National Statistics

* See Note 3.

\section{Figure 2}

\section{ABI labour productivity annual growth rates using GVA at constant prices}

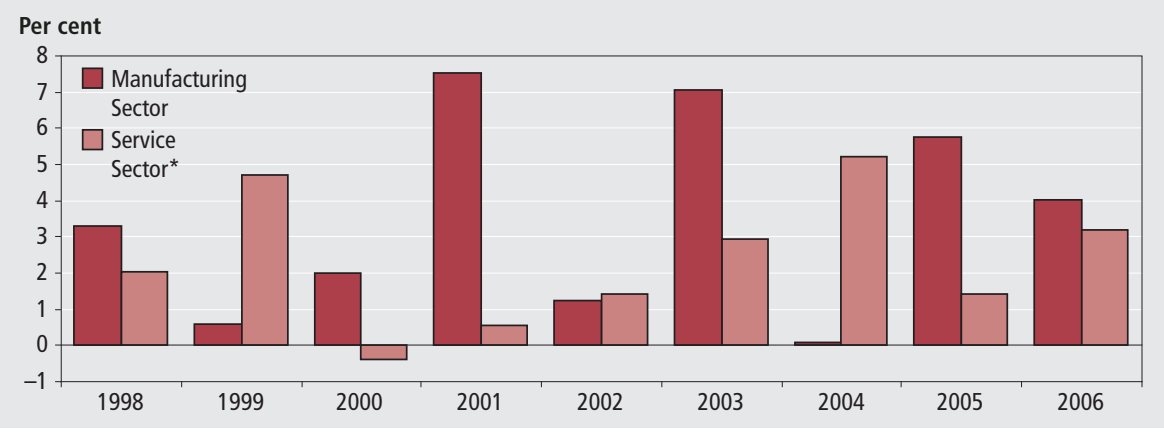

Note:

Source: Office for National Statistics

* See Note 3 .

\section{Figure 3}

\section{Scatter plot of labour productivity and capital intensity by industry ${ }^{1}$}

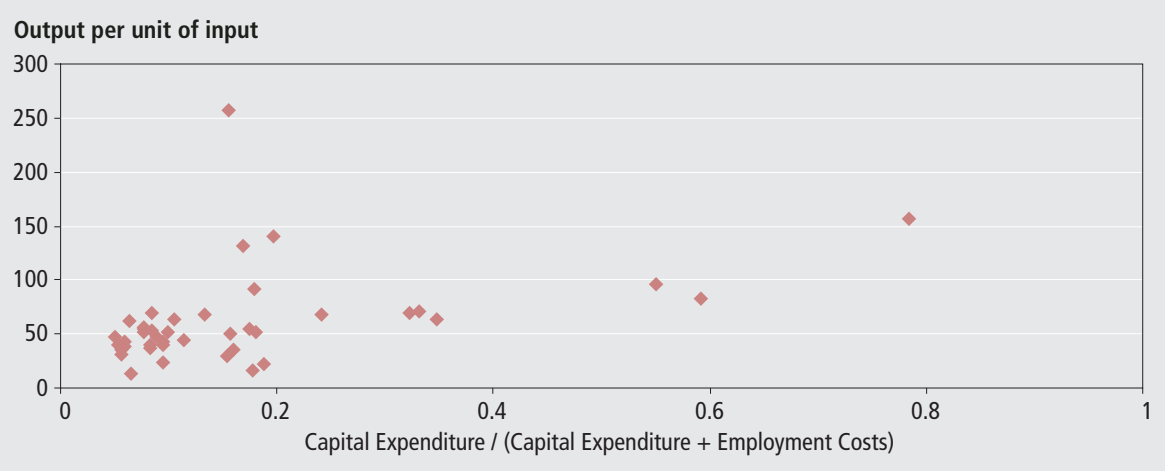

Note:

Source: Office for National Statistics

1 The data point for section 11 (Extraction of crude petroleum and natural gas; Service activities incidental to oil and gas extraction excluding surveying) has been omitted from this plot in order to allow for a more detailed scale. with 136 for the manufacturing sector. The year on year growth rates in Figure 2 show that, for the majority of the period, annual growth rates of labour productivity in the manufacturing sector outstripped those in the service sector.

Turning towards a lower level of analysis, Table 2 details the five best and worst performing divisions in terms of labour productivity levels at the two digit SIC level. Certain SIC sections at the two digit level have consistently ranked highly in terms of productivity performance. Section 11 (Extraction of crude petroleum and natural gas; service activities incidental to oil and gas extraction excluding surveying) has ranked at the top for the whole period. Section 41 (Collection, purification and distribution of water) has also ranked consistently highly. At the other end of the spectrum sections 55 (Hotels and restaurants) and 52 (Retail trade, except of motor vehicles and motorcycles; repair of personal and household goods) have ranked consistently low in labour productivity estimates.

These results are broadly consistent with Baumol's theory that more capital intensive industries are better placed to take advantage of technological advances. For example, in 2006 the ratios of capital expenditure to the sum of capital expenditure and employment costs in SIC sections 11 and 41 were 0.72 and 0.78 , respectively. The corresponding ratios for sections 55 and 52 were 0.18 and 0.19 , respectively. This relationship is explored further in Figure 3, which is a scatter plot of labour productivity levels for 2007 against capital expenditure as a proportion of capital expenditure plus employment costs for $2006^{4}$. Although the ratio is an imperfect means of capturing capital intensity,

Figure 3 suggests a broadly positive correlation between this ratio and labour productivity.

Taken as a whole the results of this tentative analysis suggest that the symptoms of Baumol's disease are still very much a feature of UK labour productivity. A more 
Table 2

Rankings of 'approximate GVA per job' for two digit SIC'

\begin{tabular}{|c|c|c|c|c|c|c|c|c|c|c|}
\hline Rank & 1998 & 1999 & 2000 & 2001 & 2002 & 2003 & 2004 & 2005 & 2006 & 2007 \\
\hline 1 & 11 & 11 & 11 & 11 & 11 & 11 & 11 & 11 & 11 & 11 \\
\hline 2 & 16 & 16 & 16 & 16 & 16 & 16 & 16 & 41 & 16 & 16 \\
\hline 3 & 41 & 23 & 23 & 23 & 41 & 41 & 41 & 61 & 41 & 41 \\
\hline 4 & 23 & 41 & 61 & 41 & 61 & 61 & 61 & 23 & 61 & 23 \\
\hline 5 & 61 & 90 & 41 & 61 & 23 & 23 & 23 & 90 & 23 & 61 \\
\hline
\end{tabular}

Panel B: Bottom Five

\begin{tabular}{|c|c|c|c|c|c|c|c|c|c|c|}
\hline Rank & 1998 & 1999 & 2000 & 2001 & 2002 & 2003 & 2004 & 2005 & 2006 & 2007 \\
\hline 1 & 91 & 91 & 91 & 91 & 91 & 91 & 91 & 91 & 91 & 91 \\
\hline 2 & 55 & 55 & 55 & 55 & 55 & 55 & 55 & 55 & 55 & 55 \\
\hline 3 & 52 & 18 & 52 & 52 & 52 & 52 & 52 & 52 & 52 & 52 \\
\hline 5 & 18 & 93 & 93 & 93 & 39 & 39 & 17 & 17 & 19 & 92 \\
\hline
\end{tabular}

Note:

1 Excluding SIC divisions 12, 13, 40, 62, 65-67, 70, 73 and 75-85.

comprehensive analysis of productivity growth and its drivers would take the form of a multi-factor productivity approach. Although the required data to perform this analysis at a 4 digit level are not currently available, Turvey (2009), performs this analysis at a broad sector level using National Accounts and labour market data.

\section{Conclusion}

Estimates of labour productivity derived from the ABI are useful in allowing for a much more detailed industry breakdown than headline productivity estimates. They also differ from the headline productivity estimates in that they are not subject to the National Accounts coherency and balancing adjustments, which reduce consistency between the input and output measures.

It is important, however, to bear in mind the limitations to these figures. For some industries, the $\mathrm{ABI}$ is not representative; for others the ABI offers no coverage at all - notably sections $\mathrm{J}$ and $\mathrm{L}$ relating to Financial intermediation and Public administration and defence respectively. Finally, note that prices in certain industrial sectors are subject to substantial volatility, which should be borne in mind when interpreting the corresponding labour productivity estimates.

A full set of labour productivity estimates at section, 2 digit and 4 digit SIC level can be found in the Appendix in Tables A1, A2 and $\mathbf{A 3}$, respectively.

\section{Notes}

1. From 2009, the part of the ABI which deals with employment, known as $\mathrm{ABI} / 1$, will be replaced with the Business Register Employment Survey (BRES). BRES will replace both the $\mathrm{ABI} / 1$ and the Business Register Survey (BRS). For more information see www.ons.gov.uk/about/surveys/az-of-surveys/business-register-andemployment-survey/index.html

2. Between 1995 and 1998 employment data was collected using the Annual Employment Survey (AES) which, due to methodological and coding differences, is not consistent with the ABI.

3. Specifically, division $\mathrm{H}$ (Hotels and restaurants) and elements of divisions I (Transport, storage and communication), $\mathrm{K}$ (Real estate, renting and business activities), $\mathrm{O}$ (Other community, social and personal service activities) and G (Wholesale and retail trade; repair of motor vehicles, motorcycles and personal and household goods).

4. The ratios for 2006 are plotted against the 2007 labour productivity estimates as it is the prior level capital expenditure that is likely to influence the current level of productivity.

\section{CONTACT}

هelmr@ons.gov.uk
Source: Office for National Statistics

\section{REFERENCES}

Baumol W J (1967) 'Macroeconomics of Unbalanced Growth: The Anatomy of Urban Crisis', American Economics Review, vol. 57, no. 3, pp. 415-426.

Daffin C and Lau E (2002) 'Labour productivity measures from the Annual Business Inquiry', Economic Trends, vol. 589, pp. 54-63. and at

www.statistics.gov.uk/cci/article.asp? $i d=276$

Goodridge P (2007) 'New labour productivity measures from the $\mathrm{ABI}-1998$ to 2005',

Economic and Labour Market Review, vol.1, no. 9, pp. 25-39. and at

www.statistics.gov.uk/cci/article. asp? $\mathrm{id}=1855$

Gough J (2007), 'Discontinuity analysis affecting the $2006 \mathrm{ABI}$ employee estimates', Economic and Labour Market Review, vol.3,

no. 12, pp. 74-77. and at www.statistics.gov.uk/cci/article. asp? $\mathrm{id}=2343$

Penneck S and Mahajan S (1999) 'Annual coherence adjustments in the National Accounts', Economic Trends, no. 551, pp. 27-32 and at

www.statistics.gov.uk/cci/article. $a s p ? i d=51$

Turvey A (2009) 'Multi-Factor Productivity: Estimates for 1998 to 2007', Economic and Labour Market Review, vol. 3, no. 3, pp. 3338. 
Table A1

Current Price 'Approximate GVA per job' for 1998 to 2007, Industry Sections ${ }^{1}$

\begin{tabular}{|c|c|c|c|c|c|c|c|c|c|c|c|c|}
\hline \multicolumn{13}{|c|}{$\mathrm{f}$ thousands } \\
\hline Section & Sub section & Industry & 1998 & 1999 & 2000 & 2001 & 2002 & 2003 & 2004 & 2005 & 2006 & 2007 \\
\hline $\mathrm{C}-\mathrm{O}$ & & All sectors covered by the $A B I$ & 28.7 & 30.1 & 31.1 & 32.1 & 32.8 & 34.0 & 36.1 & 38.0 & 40.6 & 42.8 \\
\hline$C-F$ & & Production sector plus construction & 36.1 & 38.0 & 40.1 & 41.8 & 43.9 & 45.3 & 49.0 & 53.6 & 56.8 & 60.6 \\
\hline C-E & & Production sector & 38.5 & 40.4 & 42.7 & 43.7 & 46.5 & 47.2 & 51.7 & 57.5 & 60.3 & 64.3 \\
\hline G-0 & & Service sector & 25.2 & 26.5 & 27.2 & 28.1 & 28.6 & 29.8 & 31.4 & 33.1 & 35.0 & 36.8 \\
\hline $\mathrm{H}-\mathrm{O}$ & & $\begin{array}{l}\text { Service sector excluding Wholesale } \\
\text { and Retail trade }\end{array}$ & 26.7 & 27.7 & 29.0 & 29.6 & 30.2 & 31.3 & 33.1 & 35.4 & 36.7 & 39.0 \\
\hline \multirow[t]{3}{*}{ C } & & Mining and Quarrying & 162.8 & 198.3 & 297.4 & 316.3 & 288.1 & 260.5 & 297.9 & 369.9 & 378.3 & 443.3 \\
\hline & CA & $\begin{array}{l}\text { Mining and Quarrying of Energy } \\
\text { Producing Materials }\end{array}$ & 238.0 & 295.7 & 496.0 & 533.0 & 472.2 & 428.6 & 477.9 & 601.4 & 639.2 & 693.8 \\
\hline & $\mathrm{CB}$ & $\begin{array}{l}\text { Mining and Quarrying except Energy } \\
\text { Producing Materials }\end{array}$ & 49.9 & 52.8 & 53.5 & 55.5 & 49.8 & 48.3 & 61.6 & 74.0 & 59.8 & 68.1 \\
\hline \multirow[t]{15}{*}{ D } & & Manufacturing & 33.9 & 35.2 & 35.9 & 36.6 & 39.3 & 40.2 & 43.7 & 44.6 & 48.2 & 51.4 \\
\hline & DA & $\begin{array}{l}\text { Manufacture of Food Products, } \\
\text { Beverages and Tobacco }\end{array}$ & 35.9 & 37.4 & 38.0 & 39.8 & 43.4 & 44.7 & 47.7 & * & 50.3 & 52.1 \\
\hline & DB & $\begin{array}{l}\text { Manufacture of Textiles and Textile } \\
\text { Products }\end{array}$ & 19.6 & 18.7 & 19.9 & 22.8 & 24.4 & 25.0 & 26.4 & 29.7 & 28.4 & 32.8 \\
\hline & DC & $\begin{array}{l}\text { Manufacture of Leather and Leather } \\
\text { Products }\end{array}$ & 20.1 & 24.4 & 28.9 & 28.6 & 34.4 & 27.8 & 27.0 & 30.0 & 25.7 & 31.2 \\
\hline & $\mathrm{DD}$ & $\begin{array}{l}\text { Manufacture of Wood and Wood } \\
\text { Products }\end{array}$ & 25.0 & 23.3 & 25.9 & 25.7 & 26.9 & 30.2 & 33.7 & 34.8 & 31.5 & 37.5 \\
\hline & $\mathrm{DE}$ & $\begin{array}{l}\text { Manufacture of Pulp, Paper and } \\
\text { Paper Products; Publishing and } \\
\text { Printing }\end{array}$ & 36.1 & 39.4 & 40.6 & 40.4 & 42.7 & 42.0 & 45.4 & 45.4 & 45.5 & 47.1 \\
\hline & DF & $\begin{array}{l}\text { Manufacture of Coke, Refined } \\
\text { Petroleum Products and Nuclear fuel }\end{array}$ & 84.0 & 120.0 & 88.9 & 97.5 & 87.3 & 84.4 & 103.4 & 92.8 & 117.9 & 139.8 \\
\hline & DG & $\begin{array}{l}\text { Manufacture of Chemicals, Chemical } \\
\text { Products and Man-made Fibres }\end{array}$ & 52.5 & 55.2 & 60.9 & 62.5 & 63.5 & 66.8 & 70.8 & 77.5 & 90.1 & 91.7 \\
\hline & $\mathrm{DH}$ & $\begin{array}{l}\text { Manufacture of Rubber and Plastic } \\
\text { Products }\end{array}$ & 29.8 & 28.9 & 30.7 & 31.8 & 33.2 & 34.1 & 36.0 & 38.0 & 36.5 & 40.6 \\
\hline & DI & $\begin{array}{l}\text { Manufacture of Other Non-metallic } \\
\text { Mineral Products }\end{array}$ & 32.8 & 33.5 & 34.8 & 36.0 & 40.1 & 41.9 & 46.1 & 46.0 & 48.7 & 52.1 \\
\hline & DJ & $\begin{array}{l}\text { Manufacture of Basic Metals and } \\
\text { fabricated Metal Products }\end{array}$ & 30.4 & 29.5 & 30.2 & 30.7 & 31.5 & 32.6 & 35.6 & 37.3 & 41.2 & 44.9 \\
\hline & DK & $\begin{array}{l}\text { Manufacture of Machinery and } \\
\text { Equipment not elsewhere classified }\end{array}$ & 33.0 & 32.7 & 33.5 & 32.8 & 36.9 & 38.8 & 39.8 & 42.2 & 46.5 & 47.3 \\
\hline & $\mathrm{DL}$ & $\begin{array}{l}\text { Manufacture of Electrical and Optical } \\
\text { Equipment }\end{array}$ & 35.2 & 36.6 & 39.1 & 31.4 & 37.4 & 39.7 & 44.2 & 43.5 & 47.9 & 50.1 \\
\hline & DM & Manufacture of Transport Equipment & 39.9 & 42.8 & 38.2 & 43.8 & 45.3 & 43.2 & 48.1 & 49.7 & 53.7 & 59.1 \\
\hline & DN & $\begin{array}{l}\text { Manufacturing not elsewhere } \\
\text { classified }\end{array}$ & 25.6 & 26.3 & 25.4 & 27.8 & 27.9 & 28.2 & 32.1 & 33.7 & 34.6 & 41.8 \\
\hline $\mathrm{E}$ & & Electricity, Gas and Water Supply & 109.9 & 114.9 & 107.2 & 110.6 & 132.2 & 127.4 & 135.5 & 169.9 & 187.0 & 175.4 \\
\hline $\mathrm{F}$ & & Construction & 27.2 & 29.8 & 31.6 & 35.9 & 36.7 & 40.0 & 41.9 & 45.4 & 48.5 & 52.2 \\
\hline G & & $\begin{array}{l}\text { Wholesale and retail Trade; Repair } \\
\text { of Motor Vehicles, Motorcycles and } \\
\text { Personal and Household Goods }\end{array}$ & 22.7 & 24.5 & 23.9 & 25.6 & 25.7 & 27.0 & 28.6 & 28.8 & 31.7 & 32.7 \\
\hline H & & Hotels and Restaurants & 11.3 & 11.9 & 12.6 & 13.1 & 13.8 & 13.6 & 15.0 & 14.9 & 15.6 & 16.1 \\
\hline I & & $\begin{array}{l}\text { Transport, Storage and } \\
\text { Communication }\end{array}$ & 38.5 & 38.5 & 39.7 & 39.5 & 40.4 & 43.6 & 45.4 & 48.7 & 52.9 & 55.6 \\
\hline K & & $\begin{array}{l}\text { Real Estate, Renting and Business } \\
\text { Activities }\end{array}$ & 31.1 & 32.1 & 34.0 & 34.4 & 34.8 & 36.4 & 38.2 & 40.9 & 43.0 & 46.1 \\
\hline 0 & & $\begin{array}{l}\text { Other Community, Social and } \\
\text { Personal Service Activities }\end{array}$ & 23.0 & 25.0 & 25.1 & 26.3 & 27.0 & 27.4 & 29.4 & 32.2 & 29.5 & 29.7 \\
\hline
\end{tabular}

Note:

Source: Office for National Statistics

1 Excluding SIC Divisions 12, 65-67, 70, 75-85 and also 13 in 2003-2007. 
Table A2

Current Price 'Approximate GVA per job' for 1998 to 2007, Two Digit SIC'

\begin{tabular}{|c|c|c|c|c|c|c|c|c|c|c|c|}
\hline \multirow[b]{2}{*}{ SIC03 } & & \multirow[b]{2}{*}{1998} & \multirow[b]{2}{*}{1999} & \multirow[b]{2}{*}{2000} & \multirow[b]{2}{*}{2001} & \multirow[b]{2}{*}{2002} & \multirow[b]{2}{*}{2003} & \multirow[b]{2}{*}{2004} & & \multicolumn{2}{|c|}{$f$ thousands } \\
\hline & & & & & & & & & 2005 & 2006 & 2007 \\
\hline 10 & $\begin{array}{l}\text { Mining of Coal and Lignite; } \\
\text { Extraction of Peat }\end{array}$ & 46.1 & 37.0 & 41.9 & 37.7 & 35.8 & 40.2 & 36.9 & 32.1 & 37.5 & 55.0 \\
\hline 11 & $\begin{array}{l}\text { Extraction of Crude Petroleum } \\
\text { and Natural Gas; Service Activities } \\
\text { Incidental to Oil and Gas Extraction } \\
\text { excluding Surveying }\end{array}$ & 330.1 & 419.2 & 703.0 & 766.0 & 657.3 & 573.5 & 611.5 & 744.4 & 770.1 & 820.8 \\
\hline 14 & Other Mining and Quarrying & 50.3 & 52.9 & 53.5 & 55.5 & 49.8 & 48.3 & 61.6 & 74.0 & 59.8 & 68.1 \\
\hline 15 & $\begin{array}{l}\text { Manufacture of Food Products and } \\
\text { Beverages }\end{array}$ & 33.9 & 35.3 & 35.9 & 38.2 & 41.4 & 42.8 & 45.5 & * & 48.2 & 49.9 \\
\hline 16 & Manufacture of Tobacco Products & 166.3 & 188.4 & 211.3 & 178.9 & 245.6 & 211.2 & 250.6 & * & 251.9 & 257.8 \\
\hline 17 & Manufacture of Textiles & 21.8 & 21.1 & 22.5 & 24.0 & 25.0 & 26.5 & 25.2 & 26.6 & 28.3 & 31.5 \\
\hline 18 & $\begin{array}{l}\text { Manufacture of Wearing Apparel; } \\
\text { Dressing and Dyeing of Fur }\end{array}$ & 17.0 & 15.9 & 16.8 & 21.0 & 23.4 & 22.7 & 28.8 & 36.2 & 28.5 & 35.9 \\
\hline 19 & $\begin{array}{l}\text { Tanning and Dressing of Leather; } \\
\text { Manufacture of Handbags, Saddlery, } \\
\text { Harness and Footwear }\end{array}$ & 20.1 & 24.4 & 28.9 & 28.6 & 34.4 & 27.8 & 27.0 & 30.0 & 25.7 & 31.2 \\
\hline 20 & $\begin{array}{l}\text { Manufacture of Wood and Products } \\
\text { of Wood and cork, except Furniture; } \\
\text { Manufacture of Articles of Straw and } \\
\text { Plaiting Materials }\end{array}$ & 25.0 & 23.3 & 25.9 & 25.7 & 26.9 & 30.2 & 33.7 & 34.8 & 31.5 & 37.5 \\
\hline 21 & $\begin{array}{l}\text { Manufacture of Pulp, Paper and } \\
\text { Paper Products }\end{array}$ & 35.1 & 38.0 & 37.7 & 39.2 & 43.1 & 40.2 & 40.7 & 37.4 & 36.5 & 44.6 \\
\hline 22 & $\begin{array}{l}\text { Publishing, Printing and } \\
\text { Reproduction of Recorded Media }\end{array}$ & 36.4 & 39.9 & 41.4 & 40.7 & 42.6 & 42.4 & 46.5 & 47.3 & 47.5 & 47.6 \\
\hline 23 & $\begin{array}{l}\text { Manufacture of Coke, Refined } \\
\text { Petroleum Products and Nuclear Fuel }\end{array}$ & 84.0 & 120.0 & 88.9 & 97.5 & 87.3 & 84.4 & 103.4 & 92.8 & 117.9 & 139.8 \\
\hline 24 & $\begin{array}{l}\text { Manufacture of Chemicals and } \\
\text { Chemical Products }\end{array}$ & 52.5 & 55.2 & 60.9 & 62.5 & 63.5 & 66.8 & 70.8 & 77.5 & 90.1 & 91.7 \\
\hline 25 & $\begin{array}{l}\text { Manufacture of Rubber and Plastic } \\
\text { Products }\end{array}$ & 29.8 & 28.9 & 30.7 & 31.8 & 33.2 & 34.1 & 36.0 & 38.0 & 36.5 & 40.6 \\
\hline 26 & $\begin{array}{l}\text { Manufacture of Other Non-metallic } \\
\text { Mineral Products }\end{array}$ & 32.8 & 33.5 & 34.8 & 36.0 & 40.1 & 41.9 & 46.1 & 46.0 & 48.7 & 52.1 \\
\hline 27 & Manufacture of Basic Metals & 33.8 & 30.6 & 34.8 & 32.0 & 29.3 & 30.5 & 43.5 & 43.8 & 52.5 & 67.3 \\
\hline 28 & $\begin{array}{l}\text { Manufacture of Fabricated Metal } \\
\text { Products, except Machinery and } \\
\text { Equipment }\end{array}$ & 29.4 & 29.2 & 28.9 & 30.4 & 32.1 & 33.1 & 33.9 & 35.8 & 38.8 & 40.0 \\
\hline 29 & $\begin{array}{l}\text { Manufacture of Machinery and } \\
\text { Equipment not elsewhere classified }\end{array}$ & 33.0 & 32.7 & 33.5 & 32.8 & 36.9 & 38.8 & 39.8 & 42.2 & 46.5 & 47.3 \\
\hline 30 & $\begin{array}{l}\text { Manufacture of Office Machinery and } \\
\text { Computers }\end{array}$ & 52.9 & 38.2 & 39.0 & 35.5 & 61.2 & 62.9 & 73.5 & 45.1 & 49.5 & 52.9 \\
\hline 31 & $\begin{array}{l}\text { Manufacture of Electrical Machinery } \\
\text { and Apparatus not elsewhere } \\
\text { classified }\end{array}$ & 26.8 & 29.8 & 31.2 & 30.7 & 30.4 & 32.4 & 35.6 & 38.3 & 40.3 & 42.4 \\
\hline 32 & $\begin{array}{l}\text { Manufacture of Radio, Television } \\
\text { and Communication Equipment and } \\
\text { Apparatus }\end{array}$ & 42.9 & 47.8 & 51.7 & 24.1 & 35.0 & 37.5 & 41.7 & 39.4 & 56.1 & 62.5 \\
\hline 33 & $\begin{array}{l}\text { Manufacture of Medical, Precision } \\
\text { and Optical Instruments, Watches } \\
\text { and Clocks }\end{array}$ & 32.6 & 34.0 & 36.5 & 37.3 & 40.3 & 43.1 & 48.2 & 50.9 & 51.4 & 51.0 \\
\hline 34 & $\begin{array}{l}\text { Manufacture of Motor Vehicles, } \\
\text { Trailers and Semi-Trailers }\end{array}$ & 37.4 & 33.8 & 30.4 & 37.4 & 37.5 & 37.3 & 43.9 & 43.2 & 49.3 & 55.3 \\
\hline 35 & $\begin{array}{l}\text { Manufacture of Other Transport } \\
\text { Equipment }\end{array}$ & 43.6 & 55.5 & 48.9 & 52.0 & 56.2 & 51.4 & 53.8 & 58.0 & 59.2 & 63.0 \\
\hline 36 & $\begin{array}{l}\text { Manufacturing of Furniture; } \\
\text { Manufacturing not elsewhere } \\
\text { classified }\end{array}$ & 25.5 & 26.1 & 25.1 & 27.4 & 27.3 & 27.6 & 29.7 & 32.0 & 31.4 & 38.0 \\
\hline 37 & Recycling & 28.9 & 30.9 & 30.7 & 32.7 & 35.9 & 36.3 & 59.2 & 49.1 & 60.1 & 71.6 \\
\hline 41 & $\begin{array}{l}\text { Collection Purification and } \\
\text { Distribution of Water }\end{array}$ & 94.6 & 91.8 & 78.4 & 94.4 & 129.5 & 104.7 & 117.2 & 154.1 & 159.3 & 156.4 \\
\hline 45 & Construction & 27.2 & 29.8 & 31.6 & 35.9 & 36.7 & 40.0 & 41.9 & 45.4 & 48.5 & 52.2 \\
\hline 50 & $\begin{array}{l}\text { Sale, Maintenance and Repair of } \\
\text { Motor Vehicles and Motorcycles; } \\
\text { Retail Sale of Automotive Fuel }\end{array}$ & 28.2 & 30.2 & 29.6 & 33.6 & 36.5 & 38.7 & 39.6 & 35.8 & 39.1 & 42.8 \\
\hline 51 & $\begin{array}{l}\text { Wholesale Trade and Commission } \\
\text { Trade, except of Motor Vehicles and } \\
\text { Motorcycles }\end{array}$ & 38.5 & 40.3 & 38.7 & 43.2 & 41.4 & 44.4 & 48.5 & 49.2 & 52.9 & 56.3 \\
\hline 52 & $\begin{array}{l}\text { Retail Trade, except of Motor Vehicles } \\
\text { and Motorcycles; Repair of Personal } \\
\text { and Household Goods }\end{array}$ & 14.8 & 16.4 & 16.6 & 16.8 & 17.4 & 18.0 & 18.9 & 19.5 & 21.5 & 21.5 \\
\hline 55 & Hotels and Restaurants & 11.3 & 11.9 & 12.6 & 13.1 & 13.8 & 13.6 & 15.0 & 14.9 & 15.6 & 16.1 \\
\hline 60 & $\begin{array}{l}\text { Land Transport; Transport Via } \\
\text { Pipelines }\end{array}$ & 25.9 & 27.3 & 28.6 & 27.9 & 29.5 & 28.6 & 27.3 & 30.7 & 32.8 & 36.2 \\
\hline 61 & Water Transport & 70.1 & 61.9 & 78.9 & 85.0 & 106.2 & 85.3 & 112.4 & 120.7 & 123.6 & 131.9 \\
\hline
\end{tabular}


Table A2 continued

\begin{tabular}{|c|c|c|c|c|c|c|c|c|c|c|c|}
\hline \multicolumn{12}{|c|}{$f$ thousands } \\
\hline SIC03 & & 1998 & 1999 & 2000 & 2001 & 2002 & 2003 & 2004 & 2005 & 2006 & 2007 \\
\hline 63 & $\begin{array}{l}\text { Supporting and Auxiliary Transport } \\
\text { Activities; Activities of Travel } \\
\text { Agencies }\end{array}$ & 42.3 & 42.8 & 39.5 & 41.7 & 41.5 & 45.2 & 48.5 & 51.8 & 59.0 & 63.1 \\
\hline 64 & Post and Telecommunications & 50.1 & 48.1 & 50.5 & 48.4 & 48.2 & 57.2 & 60.8 & 63.8 & 69.1 & 69.4 \\
\hline 71 & $\begin{array}{l}\text { Renting of Machinery and Equipment } \\
\text { Without Operator and of Personal } \\
\text { and Household Goods }\end{array}$ & 59.0 & 57.1 & 52.8 & 63.4 & 66.3 & 65.9 & 64.6 & 71.4 & 71.2 & 83.2 \\
\hline 72 & Computer and Related Activites & 46.7 & 47.0 & 44.2 & 46.4 & 50.0 & 51.1 & 56.2 & 61.6 & 64.5 & 70.0 \\
\hline 74 & Other Business Activities & 27.3 & 28.2 & 31.4 & 30.6 & 30.5 & 32.1 & 33.5 & 35.6 & 37.9 & 40.1 \\
\hline 90 & $\begin{array}{l}\text { Sewage and Refuse Disposal, } \\
\text { Sanitation and Similar Activities }\end{array}$ & 66.0 & 74.7 & 62.8 & 56.2 & 82.1 & 76.3 & 75.4 & 89.9 & 105.2 & 96.5 \\
\hline 91 & $\begin{array}{l}\text { Activities of Membership } \\
\text { Organisations not elsewhere } \\
\text { classified }\end{array}$ & 11.2 & 10.6 & 8.8 & 8.1 & 8.9 & 8.1 & 10.2 & 10.4 & 14.8 & 13.3 \\
\hline 92 & $\begin{array}{l}\text { Recreational, Cultural and Sporting } \\
\text { Activities }\end{array}$ & 25.7 & 27.6 & 28.7 & 30.4 & 31.3 & 31.3 & 32.5 & 35.5 & 27.9 & 30.1 \\
\hline 93 & Other Service Activities & 16.6 & 19.2 & 20.6 & 22.5 & 20.2 & 21.7 & 23.7 & 25.1 & 25.0 & 23.4 \\
\hline
\end{tabular}

Note:

Source: Office for National Statistics

1 Excluding SIC Divisions 12, 13, 40, 65-67, 70, 73 and 75-85. 
Table A3

Current Price 'Approximate GVA per job' for 1998 to 2007, Four Digit SIC'

\begin{tabular}{|c|c|c|c|c|c|c|c|c|c|c|}
\hline \multicolumn{11}{|c|}{$f$ thousands } \\
\hline $\mathrm{SICO3}$ & 1998 & 1999 & 2000 & 2001 & 2002 & 2003 & 2004 & 2005 & 2006 & 2007 \\
\hline 1010 & $\begin{array}{l}46.7 \\
\end{array}$ & 36.9 & 42.1 & 37.6 & 34.7 & 40.2 & 37.0 & 31.0 & 37.2 & 55.4 \\
\hline 1100 & 330.1 & 419.2 & 703.0 & 766.0 & 657.3 & 573.5 & 611.5 & 1361.9 & 770.1 & 820.8 \\
\hline 1411 & 49.5 & 28.4 & 46.4 & 53.4 & 53.7 & 51.8 & 54.2 & 46.1 & 61.8 & 53.2 \\
\hline 1412 & 48.2 & 59.4 & * & 50.1 & 52.9 & * & * & * & * & * \\
\hline 1421 & 56.8 & 58.8 & 56.9 & 59.5 & 50.5 & 48.1 & 69.2 & 68.7 & 64.2 & 78.0 \\
\hline 1422 & 36.5 & 44.6 & 47.6 & 41.3 & 41.9 & 43.5 & 44.3 & 47.5 & 39.8 & 56.7 \\
\hline 1430 & * & * & * & * & * & * & * & * & * & \\
\hline 1440 & 70.0 & 75.5 & 80.5 & 63.6 & 87.1 & 86.7 & 63.7 & 91.1 & * & \\
\hline 1450 & 18.5 & 38.4 & 56.9 & 55.4 & 54.3 & 43.9 & 54.2 & 38.3 & 29.0 & 36.7 \\
\hline
\end{tabular}

\section{Manufacturing}

\begin{tabular}{|c|c|c|c|c|c|c|c|c|c|c|}
\hline 1512 & & & & & & & & & & \\
\hline & 17.5 & 17.2 & 20.1 & 25.1 & 29.2 & 24.0 & 23.4 & 24.8 & 21.4 & 24.5 \\
\hline 1513 & 26.4 & 24.2 & 25.1 & 25.9 & 28.7 & 29.2 & 28.0 & 30.5 & 27.7 & 31.8 \\
\hline 1520 & 17.7 & 17.6 & 17.5 & 21.5 & 22.6 & 24.3 & 26.4 & 29.2 & 25.9 & 39.2 \\
\hline 1531 & 38.2 & 60.3 & 57.7 & 56.4 & 56.5 & 60.5 & 64.6 & 48.0 & 55.7 & 61.2 \\
\hline 1532 & 29.9 & 51.8 & 54.1 & 50.7 & 48.1 & 50.2 & 52.2 & 54.8 & 35.1 & 34.1 \\
\hline 1533 & 31.7 & 29.5 & 28.3 & 38.5 & 31.3 & 30.1 & 34.8 & 34.8 & 32.2 & 38.2 \\
\hline 1551 & 35.0 & 31.0 & 34.8 & 34.9 & 47.7 & 45.0 & 38.3 & 35.8 & 46.2 & 50.3 \\
\hline 1552 & 34.5 & 27.5 & 27.3 & 25.7 & 34.1 & 42.5 & 39.2 & 40.9 & 36.6 & 48.5 \\
\hline 1561 & 66.9 & 62.6 & 61.2 & 58.3 & * & * & * & 76.1 & 92.3 & * \\
\hline 1562 & 76.8 & 48.5 & 66.0 & 86.4 & * & * & * & 39.8 & 7.7 & * \\
\hline 1571 & 29.0 & 38.9 & 20.3 & 32.1 & 40.0 & 43.8 & 39.4 & 35.0 & 46.8 & 45.7 \\
\hline 1572 & 63.2 & 58.7 & 60.8 & 65.0 & 78.1 & 63.4 & 79.3 & 87.0 & 87.1 & 113.3 \\
\hline 1581 & 17.2 & 18.5 & 20.6 & 21.7 & 24.4 & 26.5 & 29.4 & 26.5 & 28.2 & 27.9 \\
\hline 1582 & 23.9 & 24.4 & 26.3 & 26.4 & 24.9 & 30.0 & 35.1 & 47.0 & 41.7 & 44.8 \\
\hline 1584 & 46.3 & 45.7 & 55.7 & 60.3 & 62.6 & 76.5 & 90.4 & 77.9 & 80.4 & 101.4 \\
\hline 1586 & 52.5 & 78.1 & 100.1 & 99.7 & 101.5 & 111.6 & 101.9 & 137.2 & 117.1 & 108.0 \\
\hline 1587 & 39.9 & 35.8 & 32.8 & 39.3 & 47.4 & 56.2 & 54.9 & 67.1 & 53.2 & 39.4 \\
\hline 1589 & * & 36.0 & 36.6 & 38.8 & 36.9 & 45.2 & 45.7 & 50.2 & 61.1 & 45.0 \\
\hline 1591 & 83.3 & 72.3 & 78.5 & 83.3 & 87.4 & 104.9 & 135.4 & 150.3 & 173.6 & 187.0 \\
\hline 1596 & 57.1 & 74.9 & 68.1 & 62.6 & 69.1 & 58.2 & 53.7 & 52.2 & 67.1 & 35.8 \\
\hline 1597 & 47.8 & 35.7 & 40.5 & 55.7 & 47.5 & 69.2 & 57.8 & 54.4 & 59.1 & 88.9 \\
\hline 1598 & 54.2 & 63.4 & 55.2 & 60.0 & 54.6 & 63.7 & 71.2 & 63.2 & 62.1 & 58.1 \\
\hline 1600 & 166.3 & 188.4 & 211.3 & 178.9 & 245.6 & 211.2 & * & * & 251.9 & 257.8 \\
\hline 1711 & 22.8 & 18.7 & 30.4 & 35.1 & 65.0 & * & * & 19.4 & 27.3 & 11.6 \\
\hline 1712 & 22.5 & 27.8 & 25.6 & 27.3 & 23.1 & 23.0 & 20.6 & 29.8 & 28.7 & 36.2 \\
\hline 1713 & 17.9 & 20.4 & 28.5 & 24.3 & 31.5 & 23.2 & 23.3 & 27.1 & 22.8 & 16.1 \\
\hline 1716 & 26.5 & 16.6 & 21.9 & 22.5 & 22.8 & 22.5 & 24.0 & 14.4 & $*$ & 28.7 \\
\hline 1721 & 21.5 & 17.5 & 22.2 & 24.6 & 27.5 & 17.3 & 25.0 & 15.0 & 17.4 & 15.2 \\
\hline 1722 & 20.8 & 29.3 & 18.2 & 22.2 & 22.9 & 29.8 & 24.0 & 14.1 & 16.0 & 24.6 \\
\hline 1723 & 24.8 & 21.6 & 19.1 & 33.8 & 22.9 & 22.7 & 21.4 & 19.1 & 22.0 & 37.1 \\
\hline 1724 & 27.1 & 27.2 & 25.4 & 29.7 & 31.9 & 35.0 & 32.6 & 30.1 & 32.5 & 36.4 \\
\hline 1725 & 26.8 & 12.5 & 19.6 & 18.8 & * & * & 10.7 & 31.9 & 37.4 & 168.0 \\
\hline 1730 & 25.9 & 23.2 & 25.7 & 29.8 & 33.6 & 33.7 & 28.7 & 23.9 & 27.9 & 32.6 \\
\hline 1740 & 16.5 & 21.0 & 20.0 & 22.6 & 20.9 & 27.2 & 23.5 & 28.0 & 26.5 & 26.7 \\
\hline 1751 & 25.9 & 25.4 & 26.2 & 25.4 & 29.6 & 28.1 & 30.1 & 33.7 & 34.1 & 40.7 \\
\hline 1752 & 28.7 & 24.9 & 26.1 & 31.7 & 23.5 & 28.8 & 30.0 & 23.7 & 19.8 & 41.5 \\
\hline 1753 & 37.4 & 32.9 & 31.5 & 31.0 & 43.6 & 35.7 & 34.4 & 39.7 & 31.2 & 32.6 \\
\hline 1754 & 25.8 & 19.0 & 24.1 & 25.1 & 21.9 & 28.0 & 29.7 & 27.3 & 37.1 & 43.6 \\
\hline 1760 & 28.2 & 21.7 & 24.8 & 24.6 & 28.9 & 26.3 & 23.3 & 17.9 & 27.7 & 39.2 \\
\hline 1771 & 22.4 & 20.4 & 15.8 & 17.2 & 26.0 & 19.7 & 20.7 & 22.9 & 18.8 & 25.2 \\
\hline 1772 & 16.1 & 16.0 & 20.2 & 14.9 & 18.7 & 15.2 & 17.2 & 18.2 & 24.3 & 19.1 \\
\hline 1810 & 25.8 & 33.5 & 20.1 & 15.1 & 23.3 & 44.4 & 49.2 & 27.0 & * & * \\
\hline 1821 & 17.2 & 15.9 & 24.8 & 20.9 & 31.1 & 22.4 & 25.4 & 31.7 & 34.6 & 35.4 \\
\hline 1822 & 14.9 & 17.1 & 16.8 & 24.1 & 26.5 & 27.6 & 32.7 & 28.0 & 27.9 & 43.9 \\
\hline 1823 & 20.1 & 14.6 & 17.6 & 20.6 & 16.2 & 24.6 & 22.4 & 29.9 & 28.0 & 30.7 \\
\hline 1824 & 17.8 & 14.2 & 14.1 & 17.7 & 20.8 & 16.6 & 27.5 & 31.2 & 27.9 & 29.0 \\
\hline 1910 & 22.2 & 29.7 & 28.4 & 21.2 & 34.0 & 36.2 & 40.8 & 41.0 & 36.5 & 36.7 \\
\hline 1920 & 20.3 & 26.3 & 20.3 & 19.2 & 29.8 & 21.7 & 24.3 & 31.2 & 18.9 & 29.2 \\
\hline 1930 & 19.7 & 22.8 & 33.1 & 36.2 & 36.7 & 28.9 & 24.7 & 25.7 & 29.4 & 31.1 \\
\hline 2010 & 27.1 & 27.5 & 23.5 & 23.2 & 28.0 & 31.4 & 33.7 & 40.7 & 34.1 & 42.1 \\
\hline 2020 & 43.3 & 38.5 & 37.9 & 32.2 & 35.8 & 40.8 & 44.4 & 43.4 & 57.7 & 76.2 \\
\hline 2030 & 21.3 & 20.4 & 26.0 & 26.1 & 27.1 & 30.8 & 34.9 & 34.5 & 28.3 & 34.2 \\
\hline 2040 & 28.6 & 21.8 & 25.2 & 24.6 & 23.0 & 25.7 & 27.9 & 29.9 & 29.8 & 30.9 \\
\hline 2051 & 23.4 & 21.2 & 22.6 & 23.8 & 23.6 & 24.5 & 25.6 & 29.2 & * & * \\
\hline 2052 & 25.5 & 18.4 & 28.8 & * & * & 29.9 & * & * & * & * \\
\hline 2110 & 43.7 & 49.5 & 46.8 & * & * & 51.9 & * & * & 43.1 & 67.6 \\
\hline 2121 & 31.9 & 30.8 & 29.9 & 31.1 & 34.0 & 34.2 & 37.6 & 38.4 & 32.6 & 37.0 \\
\hline 2122 & 44.8 & 43.9 & 52.0 & 55.5 & 66.4 & 59.6 & 52.4 & 41.5 & 48.6 & 53.6 \\
\hline
\end{tabular}


Table A3 continued

\begin{tabular}{|c|c|c|c|c|c|c|c|c|c|c|}
\hline & & & & & & & & & & ssands \\
\hline SIC03 & 1998 & 1999 & 2000 & 2001 & 2002 & 2003 & 2004 & 2005 & 2006 & 2007 \\
\hline 2123 & 29.8 & 35.4 & 36.7 & 29.8 & 30.9 & 37.3 & 38.5 & 40.9 & 27.8 & 33.0 \\
\hline 2124 & 24.7 & 55.0 & 32.9 & 45.0 & 40.1 & 32.8 & 30.4 & 44.3 & 31.1 & 40.7 \\
\hline 2125 & 29.5 & 35.3 & 40.3 & 36.7 & 34.0 & 30.0 & 32.6 & 32.9 & 36.4 & 38.7 \\
\hline 2211 & 44.2 & 59.0 & 49.0 & 50.8 & 52.7 & 56.1 & 55.9 & 67.2 & 62.2 & 55.6 \\
\hline 2212 & 51.1 & 53.8 & 55.2 & 50.6 & 51.7 & 47.8 & 55.1 & 54.6 & 51.7 & 54.5 \\
\hline 2213 & 42.4 & 45.2 & 50.4 & 46.9 & 48.7 & 59.5 & 56.5 & 58.4 & 57.5 & 60.3 \\
\hline 2214 & 99.7 & 26.6 & 46.1 & 48.3 & 78.4 & 75.1 & 40.8 & 41.3 & 104.4 & 54.0 \\
\hline 2215 & 10.9 & 24.7 & 25.7 & 33.3 & 35.7 & 22.3 & 37.7 & 35.2 & 40.0 & 29.7 \\
\hline 2222 & 31.9 & 33.7 & 35.6 & 34.6 & 36.9 & 34.2 & 39.5 & 34.0 & 39.0 & 40.1 \\
\hline 2223 & 27.4 & 26.8 & 25.7 & 25.5 & 25.5 & 27.4 & 29.4 & 30.0 & 30.5 & 33.1 \\
\hline 2225 & 29.8 & 30.8 & 37.8 & 39.1 & 37.9 & 31.0 & 39.0 & 51.6 & 40.4 & 43.6 \\
\hline 2231 & 62.2 & 46.0 & 63.6 & 39.6 & 27.9 & 52.2 & 61.8 & 46.1 & 23.9 & 65.0 \\
\hline 2232 & 51.6 & 53.4 & 43.3 & 53.9 & 55.1 & 48.3 & 49.2 & 45.1 & 53.0 & 46.9 \\
\hline 2233 & 43.0 & 47.8 & 21.4 & 35.9 & 40.5 & 46.1 & 21.5 & 62.6 & 79.5 & 30.0 \\
\hline 2320 & 114.4 & 171.3 & 121.0 & $*$ & * & * & * & 238.4 & * & 249.2 \\
\hline 2330 & 60.5 & 83.9 & 60.4 & * & * & * & * & * & * & 74.4 \\
\hline 2413 & 33.5 & 35.4 & 42.7 & 55.4 & 59.2 & 67.9 & 66.9 & 66.5 & 95.2 & 90.8 \\
\hline 2414 & 81.6 & 63.4 & 74.2 & 84.1 & 100.7 & 86.1 & 99.1 & 183.7 & 206.6 & 144.5 \\
\hline 2415 & 37.8 & 41.1 & 53.2 & 55.7 & 55.2 & 69.7 & 68.6 & 59.6 & 49.7 & 68.9 \\
\hline 2416 & 41.9 & 39.1 & 54.6 & 44.3 & 45.8 & 60.2 & 52.9 & 61.5 & 65.2 & 66.6 \\
\hline 2417 & 41.2 & 46.2 & 53.9 & 66.9 & 56.1 & 65.5 & 67.1 & 63.0 & 59.1 & 70.4 \\
\hline 2420 & 69.6 & 69.6 & 83.6 & 75.7 & 89.1 & 85.6 & 83.4 & 78.1 & 64.3 & 82.8 \\
\hline 2430 & 38.4 & 37.5 & 41.8 & 39.7 & 48.4 & 48.8 & 57.2 & 58.9 & 62.1 & 68.0 \\
\hline 2441 & 35.0 & 52.7 & 39.6 & 50.9 & 38.8 & 40.5 & 31.1 & 36.1 & 43.4 & 108.9 \\
\hline 2442 & 73.7 & 76.4 & 82.6 & 94.7 & 81.6 & 96.2 & 95.7 & 116.0 & 120.3 & 123.9 \\
\hline 2451 & 31.7 & 39.9 & 36.8 & 38.7 & 46.7 & 42.7 & 63.2 & 63.2 & 67.2 & 56.0 \\
\hline 2452 & 38.5 & 49.8 & 64.2 & 55.9 & 50.3 & 50.0 & 48.5 & 44.6 & 40.1 & 28.3 \\
\hline 2461 & 35.3 & 29.0 & 33.0 & 33.6 & 29.0 & 35.4 & 38.1 & 31.2 & 30.6 & 60.4 \\
\hline 2462 & 51.1 & 42.6 & 56.8 & 48.9 & 53.7 & 46.4 & 63.5 & 65.3 & 53.6 & 70.5 \\
\hline 2463 & 40.3 & 42.3 & 47.7 & 47.7 & 54.1 & 54.8 & 66.0 & 77.0 & 74.0 & 69.7 \\
\hline 2464 & 70.7 & 121.8 & 51.5 & 49.7 & 47.4 & 46.1 & * & 64.9 & 62.2 & 88.8 \\
\hline 2465 & 34.2 & 44.7 & 38.2 & 40.3 & 39.3 & 44.5 & * & 49.8 & 17.1 & 32.4 \\
\hline 2466 & 52.5 & 47.1 & 60.8 & 54.6 & 52.2 & 52.9 & 60.7 & 68.5 & 86.0 & 81.0 \\
\hline 2470 & 52.7 & 53.9 & 67.9 & 53.7 & 128.2 & 98.0 & 73.5 & 75.6 & 104.2 & 90.1 \\
\hline 2511 & 43.4 & 43.9 & 37.0 & 43.1 & 66.9 & 66.6 & 70.3 & 69.5 & 67.2 & 71.8 \\
\hline 2512 & 21.1 & 22.3 & 24.2 & 19.6 & 24.0 & 28.9 & 22.5 & 42.9 & 46.3 & 23.7 \\
\hline 2513 & 27.6 & 26.9 & 30.4 & 27.5 & 33.8 & 35.1 & 34.7 & 36.1 & 38.2 & 34.6 \\
\hline 2521 & 33.9 & 32.3 & 38.0 & 42.1 & 39.1 & 38.7 & 38.9 & 41.5 & 42.4 & 43.6 \\
\hline 2522 & 34.7 & 31.7 & 31.6 & 35.4 & 34.5 & 36.6 & 41.2 & 41.9 & 37.9 & 40.1 \\
\hline 2523 & 25.7 & 25.7 & 27.8 & 30.9 & 29.7 & 30.3 & 32.7 & 34.8 & 34.1 & 40.8 \\
\hline 2524 & 26.6 & 26.5 & 27.8 & 25.8 & 27.8 & 28.9 & 31.6 & 32.7 & 30.8 & 37.5 \\
\hline 2612 & * & * & 23.2 & * & 32.6 & * & * & 33.1 & 37.1 & 42.9 \\
\hline 2613 & 40.7 & 44.8 & 44.1 & 44.3 & 47.4 & 48.3 & 54.6 & 53.6 & 38.9 & 42.1 \\
\hline 2614 & 34.7 & 33.9 & 35.8 & 35.3 & 27.2 & 42.7 & 55.5 & 56.7 & 56.9 & 77.7 \\
\hline 2615 & 28.2 & 17.4 & 47.6 & 36.1 & 25.8 & 35.3 & 41.6 & 31.3 & 42.2 & 39.2 \\
\hline 2621 & 18.1 & 15.7 & 17.0 & 16.7 & 19.3 & 21.6 & 22.9 & 23.8 & 22.3 & 27.0 \\
\hline 2622 & 36.1 & 44.2 & 40.9 & 40.0 & 43.7 & 43.7 & 77.4 & * & 65.4 & 64.4 \\
\hline 2624 & 41.5 & 23.7 & * & * & * & * & * & * & * & , \\
\hline 2625 & 10.7 & 14.6 & 19.1 & 28.3 & 7.0 & 20.1 & 23.2 & 28.9 & 17.8 & 17.9 \\
\hline 2626 & 28.6 & 31.5 & 33.2 & 29.3 & 31.3 & 32.1 & 28.5 & 34.1 & 26.1 & 32.4 \\
\hline 2630 & 29.6 & 22.0 & 21.4 & 20.9 & 15.9 & 24.2 & 32.6 & 28.3 & 25.7 & 33.3 \\
\hline 2640 & 36.7 & 36.9 & 33.0 & 37.0 & 38.8 & 45.9 & 49.4 & 48.3 & 47.5 & 46.7 \\
\hline 2651 & 64.4 & 77.1 & 95.6 & 96.0 & 97.0 & 115.2 & 82.3 & 69.4 & 92.9 & 93.6 \\
\hline 2661 & 33.0 & 33.2 & 32.9 & 35.3 & 42.7 & 41.7 & 48.2 & 48.6 & 43.2 & 47.9 \\
\hline 2662 & 122.3 & 124.5 & 114.3 & 153.6 & 145.0 & 148.8 & 171.9 & 170.4 & 213.1 & 247.3 \\
\hline 2663 & 47.7 & 55.0 & 41.2 & 48.1 & 74.7 & 60.7 & 73.0 & 57.1 & 106.5 & 63.2 \\
\hline 2664 & 49.2 & 28.4 & 42.1 & 48.4 & 27.8 & * & * & * & * & 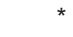 \\
\hline 2665 & 27.5 & 30.9 & 32.4 & 21.2 & 32.4 & * & * & 75.8 & * & \\
\hline 2666 & 22.9 & 24.9 & 33.0 & 50.5 & 22.1 & 29.6 & 32.9 & 30.2 & 32.3 & 30.5 \\
\hline 2670 & 24.5 & 23.5 & 23.5 & 34.0 & 40.3 & 23.2 & 28.6 & 33.5 & 30.5 & 30.7 \\
\hline 2681 & 35.4 & 24.8 & 29.0 & 30.8 & 25.5 & 29.4 & 33.7 & 35.3 & 24.5 & 32.5 \\
\hline 2682 & 36.7 & 33.0 & 44.1 & 40.5 & 44.0 & 46.2 & 46.5 & 52.7 & 58.1 & 60.9 \\
\hline 2710 & 38.7 & 32.2 & 35.3 & 18.7 & 16.3 & 21.8 & 49.2 & 39.5 & 49.9 & 91.3 \\
\hline 2721 & 23.1 & 23.3 & 34.5 & 29.4 & 34.8 & 30.0 & 32.6 & 48.6 & 74.7 & 65.5 \\
\hline 2722 & 33.1 & 29.8 & 29.8 & 39.8 & 38.3 & 34.8 & 46.4 & 53.3 & 60.8 & 58.7 \\
\hline 2731 & 22.1 & 22.4 & 26.7 & 27.1 & 28.5 & 30.1 & 40.0 & 35.2 & 37.6 & \\
\hline 2732 & 45.1 & 37.8 & 32.3 & 39.7 & 24.5 & 36.5 & 54.1 & 16.7 & 32.5 & * \\
\hline 2733 & 37.1 & 26.9 & 38.9 & 26.8 & 26.9 & 37.7 & 50.1 & 53.0 & 63.6 & 52.0 \\
\hline 2734 & 26.3 & 39.0 & 27.3 & 26.6 & 27.4 & 34.4 & 33.2 & 45.4 & 43.7 & 48.4 \\
\hline
\end{tabular}


Table A3 continued

\begin{tabular}{|c|c|c|c|c|c|c|c|c|c|c|}
\hline & & & & & & & & & & ssands \\
\hline SIC03 & 1998 & 1999 & 2000 & 2001 & 2002 & 2003 & 2004 & 2005 & 2006 & 2007 \\
\hline $2735^{* * * * *}$ & 32.4 & 22.9 & 57.1 & 15.6 & 19.3 & ** & ** & ** & ** & ** \\
\hline 2741 & 66.2 & 99.2 & 117.9 & 187.3 & 104.1 & 72.7 & 130.0 & 161.6 & 169.6 & 182.2 \\
\hline 2742 & 39.8 & 39.8 & 37.9 & 41.7 & 40.5 & 39.6 & 44.6 & 53.1 & 62.4 & 65.8 \\
\hline 2743 & 31.5 & 24.1 & 37.0 & 39.9 & 31.0 & 48.6 & 94.1 & 76.8 & 58.2 & 161.2 \\
\hline 2744 & 33.1 & 24.4 & 43.6 & 32.4 & 28.9 & 39.3 & 38.0 & 33.5 & 53.2 & 52.1 \\
\hline 2745 & 45.6 & 35.4 & 41.8 & 45.7 & 44.6 & 48.7 & 52.1 & 54.3 & 56.7 & 66.3 \\
\hline 2751 & 26.6 & 24.8 & 26.7 & 27.8 & 28.8 & 27.4 & 31.3 & 32.7 & 44.2 & 35.3 \\
\hline 2752 & 24.2 & 24.1 & 27.2 & 25.6 & 31.4 & 35.2 & 33.2 & 33.0 & 30.2 & 44.1 \\
\hline 2753 & 23.6 & 19.9 & 26.6 & 25.8 & 30.9 & 28.5 & 28.8 & 32.2 & 36.2 & 27.1 \\
\hline 2754 & 24.3 & 24.1 & 34.3 & 33.7 & 25.1 & 22.9 & 29.3 & 34.3 & 34.5 & 33.6 \\
\hline 2811 & 33.5 & 33.5 & 30.7 & 31.8 & 32.7 & 35.2 & 35.7 & 34.3 & 42.0 & 48.4 \\
\hline 2812 & 30.0 & 25.1 & 26.0 & 30.4 & 28.3 & 28.1 & 34.9 & 33.2 & 36.5 & 40.0 \\
\hline 2821 & 26.3 & 27.5 & 28.0 & 36.9 & 32.5 & 42.9 & 39.0 & 41.8 & 39.1 & 33.5 \\
\hline 2822 & 34.9 & 37.3 & 31.1 & 36.5 & 37.6 & 35.7 & 37.3 & 49.8 & 48.8 & 59.7 \\
\hline 2830 & 38.6 & 32.8 & 38.3 & 39.8 & 39.4 & 41.2 & 48.6 & 56.3 & 63.6 & 53.9 \\
\hline 2840 & 27.8 & 27.7 & 29.0 & 30.7 & 28.4 & 25.3 & 27.1 & 29.6 & 37.5 & 35.4 \\
\hline 2851 & 30.0 & 27.5 & 24.6 & 27.7 & 29.0 & 29.2 & 29.6 & 31.2 & 34.2 & 35.7 \\
\hline 2852 & 28.4 & 28.7 & 29.0 & 27.8 & 30.3 & 31.8 & 33.2 & 35.5 & 36.0 & 35.4 \\
\hline 2861 & 30.5 & 29.8 & 18.1 & * & * & * & 36.7 & 87.0 & 92.0 & 65.2 \\
\hline 2862 & 31.2 & 24.1 & 31.1 & 30.1 & 35.9 & 32.5 & 31.6 & 37.5 & 34.4 & 32.2 \\
\hline 2863 & 20.3 & 25.0 & 22.1 & * & * & * & 30.8 & 33.2 & 37.8 & 34.7 \\
\hline 2871 & 26.5 & 29.4 & 23.5 & 25.3 & 27.3 & 29.7 & 43.0 & 31.0 & 58.2 & 52.3 \\
\hline 2872 & 52.4 & 59.7 & 60.8 & 59.9 & 66.3 & 55.8 & 54.2 & 59.8 & 55.2 & 58.1 \\
\hline 2873 & 26.3 & 32.9 & 29.1 & 28.8 & 33.3 & 36.5 & 41.1 & 46.3 & 43.2 & 76.4 \\
\hline 2874 & 25.8 & 25.7 & 25.4 & 26.5 & 26.6 & 33.7 & 36.2 & 28.2 & 35.1 & 36.8 \\
\hline 2875 & 24.6 & 26.5 & 26.6 & 25.4 & 27.7 & 29.7 & 33.1 & 36.6 & 36.5 & 34.7 \\
\hline 2911 & 53.3 & 42.2 & 34.9 & 41.9 & 48.8 & 38.9 & 57.5 & 62.9 & 58.8 & 53.3 \\
\hline 2912 & 36.8 & 33.2 & 38.6 & 35.0 & 33.9 & 38.8 & 40.4 & 43.5 & 49.5 & 45.9 \\
\hline 2913 & 34.8 & 33.7 & 35.8 & 36.9 & 38.8 & 37.3 & 39.1 & 41.1 & 36.2 & 47.4 \\
\hline 2914 & 32.8 & 29.9 & 32.9 & 28.7 & 32.9 & 35.4 & 23.6 & 32.1 & 37.5 & 45.1 \\
\hline 2921 & 25.3 & 27.2 & 33.8 & 34.1 & 35.7 & 40.6 & 42.4 & 34.5 & 40.8 & 41.0 \\
\hline 2922 & 30.6 & 31.8 & 35.6 & 29.8 & 36.6 & 38.6 & 39.2 & 47.4 & 49.4 & 49.2 \\
\hline 2923 & 33.3 & 30.9 & 29.4 & 37.6 & 38.1 & 37.5 & 38.5 & 43.4 & 46.5 & 47.4 \\
\hline 2924 & 30.2 & 30.2 & 30.4 & 32.1 & 28.9 & 36.3 & 39.1 & 34.4 & 39.2 & 45.3 \\
\hline 2931 & 49.7 & 36.0 & 41.2 & 51.2 & 68.1 & 76.6 & * & 7.0 & 11.7 & 58.2 \\
\hline 2932 & 23.2 & 29.1 & 27.2 & 25.8 & 32.3 & 33.8 & * & 34.5 & 37.5 & 34.1 \\
\hline 2940 & 32.7 & 42.6 & 39.5 & 30.9 & 40.9 & 32.1 & 34.5 & 44.2 & 41.5 & 45.9 \\
\hline 2951 & 37.5 & 25.4 & 25.8 & 34.9 & 29.5 & 76.7 & 41.4 & 42.5 & 53.9 & 56.7 \\
\hline 2952 & 39.8 & 46.0 & 33.6 & 40.9 & 48.5 & 58.7 & 53.0 & 46.7 & 65.0 & 63.5 \\
\hline 2953 & 29.8 & 34.2 & 32.1 & 30.4 & 36.0 & 37.6 & 39.0 & 44.9 & 52.0 & 40.2 \\
\hline 2954 & 21.3 & 20.8 & 27.7 & 21.9 & 31.7 & 30.4 & 28.3 & 38.3 & 43.3 & 28.5 \\
\hline 2955 & 25.3 & 19.6 & 38.6 & 41.5 & 32.5 & 26.8 & 41.6 & 31.9 & 39.0 & 50.6 \\
\hline 2956 & 35.5 & 32.3 & 33.5 & 30.7 & 34.6 & 35.5 & 39.0 & 41.9 & 42.9 & 44.5 \\
\hline 2960 & 32.1 & 32.7 & 37.9 & 31.4 & 42.7 & 44.6 & 46.3 & 56.0 & 66.8 & 63.8 \\
\hline 2971 & 27.0 & 25.0 & 30.0 & 28.8 & 35.8 & 38.3 & 42.7 & 30.9 & 38.8 & 36.0 \\
\hline 2972 & 24.1 & 28.4 & 28.4 & 22.0 & 27.6 & 27.4 & 33.8 & 33.4 & 34.7 & 23.2 \\
\hline 3001 & 20.2 & 18.3 & 30.6 & 27.1 & 31.5 & 45.6 & 49.3 & 40.9 & 48.3 & 52.2 \\
\hline 3002 & 62.5 & 43.4 & 41.3 & 37.7 & 70.3 & 67.7 & 82.1 & 47.1 & 50.2 & 53.2 \\
\hline 3110 & 24.3 & 29.9 & 31.4 & 28.0 & 28.4 & 30.7 & 34.5 & 43.3 & 48.2 & 48.7 \\
\hline 3120 & 31.9 & 32.7 & 31.6 & 33.9 & 34.4 & 34.8 & 39.0 & 37.5 & 35.9 & 38.1 \\
\hline 3130 & 26.6 & 26.2 & 29.5 & 30.4 & 25.7 & 34.9 & 42.1 & 25.1 & 31.6 & 47.7 \\
\hline 3140 & 28.1 & 26.4 & 29.5 & 23.2 & 25.6 & 27.7 & 27.3 & 34.9 & 35.7 & 47.2 \\
\hline 3150 & 22.1 & 26.4 & 28.3 & 26.6 & 29.1 & 29.0 & 27.9 & 39.1 & 44.9 & 35.8 \\
\hline 3161 & 19.3 & 29.8 & 32.5 & 25.8 & 28.0 & 30.2 & 28.5 & 27.6 & 27.9 & 54.6 \\
\hline 3162 & 28.4 & 30.6 & 33.4 & 33.9 & 30.8 & 32.7 & 38.3 & 38.3 & 44.2 & 41.5 \\
\hline 3210 & 36.5 & 38.6 & 44.7 & 34.5 & 39.5 & 39.0 & 40.2 & 45.2 & 41.1 & 47.7 \\
\hline 3220 & 63.2 & 69.3 & 65.5 & 10.0 & 27.2 & 38.5 & 41.8 & 54.5 & 64.0 & 73.9 \\
\hline 3230 & 25.8 & 26.0 & 34.4 & 32.8 & 40.9 & 34.1 & 43.8 & 34.9 & 71.1 & 73.0 \\
\hline 3310 & 31.2 & 36.1 & 37.3 & 34.2 & 41.5 & 37.2 & 41.2 & 43.7 & 45.3 & 45.7 \\
\hline 3320 & 33.0 & 33.0 & 38.8 & 40.3 & 43.8 & 50.5 & 54.7 & 50.4 & 59.9 & 53.7 \\
\hline 3330 & 39.4 & 39.3 & 38.0 & 28.6 & 40.1 & 37.2 & 45.9 & 61.5 & 43.8 & 53.1 \\
\hline 3340 & 30.4 & 32.9 & 25.7 & 36.1 & 24.4 & 30.2 & 37.7 & 37.7 & 40.1 & 51.5 \\
\hline 3350 & 20.9 & 23.4 & 28.7 & 23.6 & 29.7 & 34.4 & 37.4 & 38.3 & 36.7 & 62.3 \\
\hline 3410 & 44.2 & 38.3 & 31.9 & 46.6 & 44.8 & 44.9 & 56.5 & 49.9 & 62.3 & 73.8 \\
\hline 3420 & 26.1 & 26.2 & 26.0 & 26.4 & 29.8 & 30.7 & 33.4 & 36.8 & 38.9 & 37.1 \\
\hline 3430 & 32.7 & 30.9 & 29.9 & 31.8 & 32.6 & 32.0 & 34.3 & 37.7 & 38.9 & 41.4 \\
\hline 3511 & 34.2 & 51.5 & 30.6 & 28.0 & 29.1 & 33.8 & 37.4 & 31.2 & 35.9 & 57.3 \\
\hline 3512 & 21.4 & 22.8 & 23.4 & 38.5 & 25.9 & 26.9 & 32.8 & 28.0 & 30.6 & 33.6 \\
\hline 3520 & * & 46.0 & 37.0 & 34.0 & 36.9 & 32.5 & 28.7 & 54.4 & 53.3 & 34.1 \\
\hline
\end{tabular}


Table A3 continued

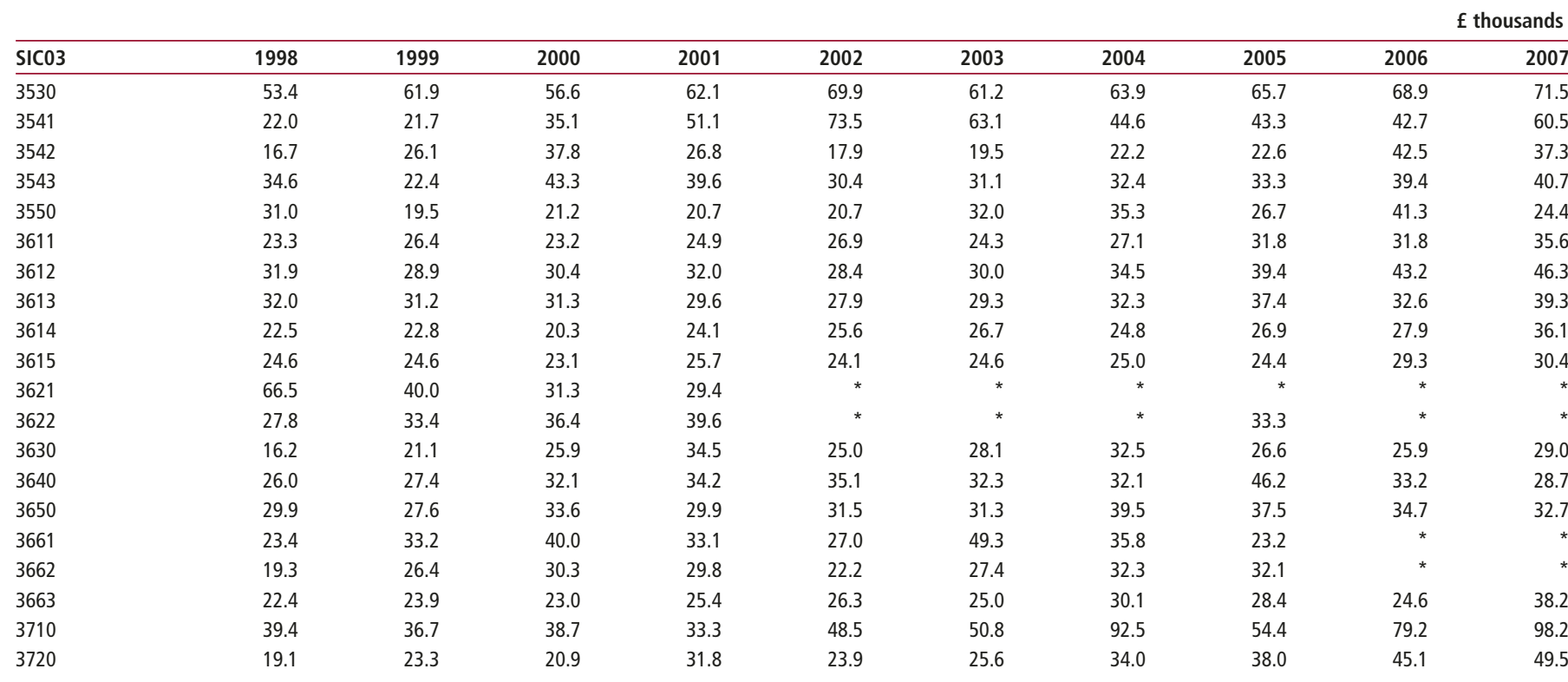

Electricity, gas and water supply

4100

91.8

\section{$78.4-94.4$}

129.5

104.7

117.2

154.1

156

Construction
4511

4512

4521

4522
4523

4524

4525

4531
4532

4533

4534

4541
4542

4543

4544

4545

4550

$\begin{array}{ll}32.0 & 34.1 \\ 67.6 & 50.4 \\ 28.6 & 32.1 \\ 23.1 & 26.4 \\ 26.6 & 28.2 \\ 42.2 & 25.6 \\ 22.8 & 32.7 \\ 27.3 & 27.5 \\ 31.9 & 29.1 \\ 28.5 & 25.5 \\ 19.8 & 21.6 \\ 30.9 & 30.7 \\ 27.3 & 26.5 \\ 27.8 & 27.9 \\ 18.8 & 22.8 \\ 25.5 & 31.4 \\ 29.8 & 36.0\end{array}$

39.9
25.0
34.0
29.4
26.6
36.9
35.3
29.4
28.2
26.8
29.3
25.4
32.2
35.0
26.1
24.9
31.5

$\begin{array}{ll}39.2 & 44.3 \\ 43.8 & 25.0 \\ 40.5 & 42.3 \\ 30.1 & 33.2 \\ 34.0 & 34.6 \\ 17.5 & 33.9 \\ 34.0 & 37.4 \\ 31.9 & 34.4 \\ 30.3 & 31.2 \\ 29.9 & 31.9 \\ 32.8 & 27.5 \\ 32.9 & 32.5 \\ 35.2 & 28.4 \\ 37.2 & 42.0 \\ 26.0 & 26.8 \\ 34.3 & 21.9 \\ 39.6 & 40.3\end{array}$

36.2
27.6
48.5
34.7
34.0
80.6
30.0
35.6
38.4
34.5
36.1
34.6
37.4
39.6
28.0
31.4
34.7

\section{0}

26.9
51.4

51.4

35.0

$$
40.2
$$

59.0

34.4

37.1

37.3

34.6

$$
\begin{aligned}
& 34.6 \\
& 28.4 \\
& 51.1
\end{aligned}
$$

32.6

32.4

27.6

37.6

Distribution

5010

5020

5030

5040
5050

5110

5120

5131

5133

5134

5135-37

5138

5139

5141

5142

5143

5144

5145

5146

5147

5151

5152

5153

5154

$\begin{array}{rrr}34.9 & 37.7 & 35.8 \\ 22.4 & 25.3 & 24.2 \\ 24.5 & 24.2 & 23.6 \\ 33.3 & 20.1 & 36.1 \\ 17.0 & 18.5 & 22.8 \\ 40.0 & 40.4 & 36.8 \\ 24.8 & 31.2 & 23.8 \\ 32.7 & 23.0 & 22.6 \\ 22.4 & 29.4 & 25.6 \\ 33.4 & 29.2 & 31.7 \\ 50.0 & 46.5 & 46.0 \\ 6.6 & 117.3 & 36.4 \\ 26.8 & 33.3 & 23.9 \\ 16.5 & 23.1 & 20.0 \\ 40.0 & 35.3 & 36.4 \\ 37.0 & 38.0 & 35.7 \\ 62.0 & 53.0 & 53.5 \\ 33.7 & 37.7 & 33.6 \\ 28.9 & 23.5 & 35.0 \\ 44.5 & 63.9 & 60.8 \\ 32.4 & 38.3 & 36.0 \\ 69.4 & 107.4 & 72.4 \\ 30.4 & 39.2 & 32.0 \\ 29.8 & 27.7 & 28.1 \\ 30.3 & 30.5 & 28.5\end{array}$

$35.8 \quad 43.5$

43.5
24.6

25.2

25.2
29.2

28.3

28.3
45.0

31.4

31.8

28.3

28.8

61.8

81.6

21.5

26.2

41.1

40.9

54.9

27.7

33.9

63.2

31.3

94.1

35.8

34.7

$\begin{array}{rrr}47.6 & 51.3 & 51.1 \\ 25.8 & 25.9 & 24.6 \\ 30.3 & 30.9 & 36.1 \\ 30.9 & 32.9 & 30.9 \\ 23.8 & 31.2 & 39.5 \\ 40.9 & 49.3 & 67.3 \\ 25.3 & 32.3 & 29.4 \\ 42.8 & 33.0 & 36.7 \\ 29.0 & 27.2 & 34.9 \\ 34.7 & 27.0 & 43.4 \\ 63.7 & 49.7 & 54.5 \\ 50.7 & 19.3 & 45.2 \\ 28.2 & 27.8 & 39.5 \\ 25.2 & 33.2 & 32.2 \\ 40.0 & 39.3 & 36.1 \\ 40.7 & 53.1 & 52.3 \\ 53.3 & 54.9 & 60.0 \\ 31.1 & 26.1 & 29.5 \\ 31.7 & 35.0 & 36.3 \\ 66.3 & 80.7 & 71.0 \\ 37.0 & 35.1 & 37.2 \\ 126.8 & 212.3 & 276.4 \\ 43.0 & 40.8 & 54.8 \\ 29.6 & 38.0 & 38.6 \\ 31.2 & 32.3 & 35.8\end{array}$

49.6

36.6
28.0
54.6
40.6
45.5
54.4
46.7
39.2
36.7
32.6
43.0
49.1
39.8
34.2
32.5
34.8
48.6

$\begin{array}{rr}* & 49.5 \\ 24.6 & 156.4 \\ 79.2 & 50.6 \\ 44.0 & 52.3 \\ 45.6 & 45.2 \\ 89.0 & 86.4 \\ 51.5 & 53.9 \\ 43.7 & 36.8 \\ 29.2 & 37.8 \\ 35.3 & 44.5 \\ 30.6 & 39.1 \\ 50.8 & 54.7 \\ 51.8 & 50.8 \\ 47.8 & 49.6 \\ 34.1 & 40.0 \\ 40.7 & 40.8 \\ 54.7 & 58.4\end{array}$

29.1

31.2

32.3

35.8

$\begin{array}{rrr}48.2 & 51.9 & 54.7 \\ 26.8 & 27.3 & 31.9 \\ 27.5 & 30.7 & 38.6 \\ 19.8 & 29.8 & 32.8 \\ 31.6 & 34.8 & 30.8 \\ 50.7 & 44.3 & 48.6 \\ 33.8 & 35.2 & 43.4 \\ 38.0 & 37.9 & 31.4 \\ 35.1 & 49.4 & 38.1 \\ 54.7 & 56.8 & 57.2 \\ 47.8 & 50.7 & 65.2 \\ 66.8 & 44.2 & 30.8 \\ 36.5 & 36.8 & 50.2 \\ 25.7 & 42.0 & 40.8 \\ 35.7 & 40.0 & 49.3 \\ 50.0 & 38.8 & 52.9 \\ 43.0 & 59.8 & 72.8 \\ 27.2 & 25.9 & 26.8 \\ 34.9 & 27.5 & 44.2 \\ 97.0 & 86.6 & 103.7 \\ 37.3 & 41.9 & 35.8 \\ 282.9 & 263.9 & 215.6 \\ 60.0 & 69.2 & 83.3 \\ 37.4 & 41.6 & 48.9 \\ 37.7 & 42.3 & 36.3\end{array}$


Table A3 continued

\begin{tabular}{|c|c|c|c|c|c|c|c|c|c|c|}
\hline SIC03 & 1998 & 1999 & 2000 & 2001 & 2002 & 2003 & 2004 & 2005 & 2006 & 2007 \\
\hline 5155 & 58.0 & 65.6 & 50.1 & 55.3 & 39.8 & 46.8 & 52.2 & 61.5 & 49.3 & 47 \\
\hline 5156 & 44.4 & 44.0 & 45.8 & 38.2 & 32.5 & 40.5 & 38.1 & 85.7 & 43.5 & \\
\hline 5157 & 31.1 & 31.4 & 28.0 & 36.3 & 36.4 & 44.3 & 53.9 & 69.7 & 53.4 & 93 \\
\hline $5164^{* * * * *}$ & 57.0 & 49.0 & 61.9 & 66.9 & 58.2 & ** & ** & ** & ** & \\
\hline $5170^{* * * * *}$ & 33.0 & 28.3 & 32.2 & 40.8 & 29.4 & $* *$ & $* *$ & ** & ** & \\
\hline $5181^{* * *}$ & 44.3 & 37.8 & 30.6 & 43.3 & 30.7 & 29.1 & 37.6 & 39.8 & 52.0 & 47 \\
\hline $5182^{* * *}$ & 44.1 & 35.4 & 41.4 & 46.8 & 42.2 & 47.6 & 53.9 & 53.5 & 48.9 & 71 \\
\hline $5183^{* * *}$ & 37.2 & 27.9 & 40.4 & 49.8 & 30.6 & 34.1 & 42.5 & 39.4 & 44.8 & \\
\hline $5184^{* * * *}$ & ** & ** & ** & ** & ** & 52.0 & ** & ** & ** & \\
\hline $5185^{* * * *}$ & $* *$ & ** & ** & ** & ** & 42.9 & ** & ** & ** & \\
\hline $5186^{* * * *}$ & $* *$ & ** & ** & ** & ** & 48.7 & ** & ** & ** & \\
\hline $5187^{* * *}$ & 51.1 & 47.6 & 47.0 & 50.8 & 45.7 & 46.2 & 43.4 & 55.0 & 64.3 & \\
\hline $5188^{* * *}$ & 23.9 & 24.9 & 26.0 & 30.3 & 37.6 & 36.5 & 44.5 & 45.8 & 40.3 & \\
\hline $5190^{* * * *}$ & ** & ** & ** & ** & ** & 35.2 & ** & ** & ** & \\
\hline 5211 & 16.2 & 17.3 & 16.9 & 14.6 & 14.4 & 14.6 & 14.9 & 15.7 & 17.4 & \\
\hline 5212 & 15.5 & 14.3 & 15.4 & 17.0 & 19.7 & 20.9 & 19.9 & 21.8 & 28.8 & \\
\hline 5221 & 8.9 & 10.8 & 10.2 & 12.5 & 12.6 & 12.5 & 14.8 & 14.6 & 16.3 & \\
\hline 5222 & 13.0 & 14.6 & 13.8 & 13.3 & 17.5 & 16.1 & 17.1 & 19.5 & 19.3 & \\
\hline 5223 & 14.2 & 12.1 & 13.9 & 15.7 & 15.2 & 17.4 & 13.6 & 19.0 & 15.2 & \\
\hline 5224 & 9.6 & 12.5 & 11.2 & 12.3 & 12.5 & 11.8 & 13.4 & 14.2 & 15.3 & \\
\hline 5225 & 7.0 & 6.0 & 7.7 & 7.2 & 8.7 & 8.2 & 9.0 & 7.5 & 5.4 & \\
\hline 5226 & 6.4 & 7.8 & 8.3 & 9.9 & 7.3 & 9.0 & 11.2 & 12.4 & 7.6 & \\
\hline 5227 & 11.3 & 14.3 & 13.8 & 15.3 & 15.3 & 14.8 & 15.3 & 16.6 & 17.5 & \\
\hline 5231 & 15.7 & 15.4 & 16.4 & 18.5 & 21.4 & 20.1 & 23.6 & 27.7 & 33.7 & \\
\hline 5232 & 13.4 & 8.6 & 29.5 & 28.2 & 30.1 & 33.7 & 38.4 & 27.5 & 40.8 & \\
\hline 5233 & 10.5 & 15.2 & 12.1 & 12.1 & 15.7 & 15.6 & 19.1 & 15.6 & 24.2 & \\
\hline 5241 & 12.0 & 14.5 & 15.9 & 15.0 & 15.3 & 15.3 & 16.6 & 14.9 & 12.6 & \\
\hline 5242 & 12.6 & 18.7 & 17.6 & 19.1 & 19.2 & 20.4 & 20.8 & 22.4 & 25.3 & 3 \\
\hline 5243 & 10.5 & 10.3 & 11.9 & 13.1 & 14.5 & 15.8 & 16.3 & 18.5 & 18.6 & 17 \\
\hline 5244 & 19.1 & 21.2 & 23.1 & 24.0 & 23.8 & 25.1 & 26.8 & 23.0 & 23.4 & 21 \\
\hline 5245 & 18.6 & 16.1 & 18.9 & 22.5 & 22.6 & 20.6 & 25.3 & 23.2 & 27.6 & 25 \\
\hline 5246 & 17.5 & 22.3 & 20.9 & 20.7 & 21.8 & 21.7 & 23.9 & 22.2 & 24.3 & 2 \\
\hline 5247 & 10.5 & 11.0 & 12.3 & 13.9 & 14.8 & 14.7 & 15.2 & 14.5 & 16.6 & 17 \\
\hline 5248 & 13.9 & 16.5 & 17.3 & 19.0 & 19.2 & 21.8 & 22.1 & 20.7 & 22.0 & 23 \\
\hline 5250 & 20.1 & 20.2 & 23.1 & 27.4 & 23.9 & 21.8 & 31.4 & 32.7 & 27.3 & \\
\hline 5261 & 26.4 & 23.3 & 15.9 & 19.4 & 24.1 & 23.6 & 28.9 & 30.4 & 40.4 & \\
\hline 5262 & 8.6 & 9.5 & 8.5 & 8.9 & 6.7 & 9.5 & 9.6 & 16.0 & 10.7 & 10 \\
\hline 5263 & 18.1 & 16.9 & 24.9 & 22.5 & 22.7 & 21.6 & 23.2 & 30.7 & 29.8 & \\
\hline 5270 & 13.9 & 19.2 & 19.6 & 17.3 & 17.0 & 18.1 & 21.2 & 22.4 & 29.1 & \\
\hline
\end{tabular}

Hotels and catering

$\begin{array}{lrrrrrrrrrr}5510 & 15.9 & 18.1 & 18.6 & 19.2 & 18.7 & 18.6 & 20.5 & 20.9 & 22.4 & 23.5 \\ 5521 & 13.2 & 12.6 & 17.9 & 13.9 & 13.4 & 14.0 & 14.2 & 14.2 & 9.9 & 14.5 \\ 5522 & 36.5 & 18.7 & 32.7 & 34.6 & 32.2 & 34.4 & 38.7 & 42.0 & 38.1 & 40.3 \\ 5523 & 15.7 & 14.4 & 18.8 & 17.1 & 20.9 & 19.4 & 20.5 & 23.1 & 19.0 \\ 5530 & 9.8 & 10.4 & 11.6 & 11.9 & 12.0 & 11.8 & 12.5 & 12.6 & 12.8 \\ 5540 & 10.3 & 10.4 & 10.5 & 11.6 & 12.7 & 12.9 & 14.7 & 13.8 & 15.3 & 14.0 \\ 5551 & 8.1 & * & 9.8 & 11.7 & 13.7 & 16.5 & 7.6 & 21.8 & 8.4 & 12.3 \\ 5552 & 9.6 & 9.8 & 10.3 & 10.1 & 13.1 & 11.6 & 13.8 & 14.7 & 13.6 & 14.2\end{array}$

Transport, storage and communication

$\begin{array}{rrrrrrrrrrr}6010 & 32.9 & 39.2 & 47.2 & 50.8 & 60.0 & 42.2 & 36.0 & 44.3 & 44.7 & 47.6 \\ 6021 & 27.9 & 25.7 & 24.6 & 22.6 & 22.7 & 25.5 & 25.2 & 25.9 & 30.0 & 31.6 \\ 6022 & 18.0 & 17.6 & 17.0 & 14.1 & 18.2 & 18.1 & 18.0 & 18.3 & 18.3 & 23.7 \\ 6023 & 16.8 & 18.5 & 18.4 & 14.7 & 18.6 & 20.2 & 20.6 & 26.3 & 23.6 & 22.6 \\ 6024 & 25.3 & 27.7 & 29.1 & 29.2 & 29.8 & 29.7 & 28.3 & 32.3 & 34.6 & 38.7 \\ 6110 & 74.0 & 71.7 & 84.8 & 93.7 & 115.1 & 94.1 & 117.9 & 126.3 & 135.0 & 141.2 \\ 6120 & 16.3 & 18.2 & 34.5 & 28.1 & 32.9 & 27.0 & 37.3 & 26.6 & 19.9 & 29.1 \\ 6311 & 27.6 & 35.9 & 37.8 & 37.4 & 41.8 & 48.0 & 46.4 & 55.5 & 66.7 & 65.2 \\ 6312 & 29.7 & 31.5 & 29.7 & 29.9 & 30.2 & 34.3 & 35.0 & 38.5 & 38.4 & 38.9 \\ 6321 & 88.7 & 92.6 & 67.6 & 81.8 & 69.5 & 52.1 & 85.1 & 65.0 & 98.4 & 100.9 \\ 6322 & 53.3 & 65.4 & 53.0 & 53.2 & 66.4 & 71.5 & 63.7 & 64.3 & 82.4 & 79.0 \\ 6323 & 95.6 & 85.9 & 83.8 & 92.7 & 84.6 & 86.4 & 91.4 & 96.6 & 92.5 & 82.7 \\ 6330 & 25.6 & 25.0 & 24.3 & 27.2 & 29.6 & 37.1 & 31.4 & 39.1 & 37.5 & 47.2 \\ 6340 & 39.6 & 43.7 & 45.2 & 37.1 & 37.0 & 38.9 & 43.1 & 52.3 & 57.6 & 69.3 \\ 6412 & 30.0 & 27.4 & * & * & * & * & * & 27.7 & * \\ 6420 & 84.9 & 82.4 & 83.7 & 73.2 & 80.9 & 97.2 & 111.1 & 115.5 & 119.3 & 123.4\end{array}$


Table A3 continued

\begin{tabular}{|c|c|c|c|c|c|c|c|c|c|c|}
\hline \multirow{2}{*}{$\overline{\text { SIC03 }}$} & \multirow[b]{2}{*}{1998} & \multirow[b]{2}{*}{1999} & \multirow[b]{2}{*}{2000} & \multirow[b]{2}{*}{2001} & \multirow[b]{2}{*}{2002} & \multirow[b]{2}{*}{2003} & \multirow[b]{2}{*}{2004} & & \multicolumn{2}{|c|}{$f$ thousands } \\
\hline & & & & & & & & 2005 & 2006 & 2007 \\
\hline \multicolumn{11}{|c|}{ Renting and business activities } \\
\hline 7110 & 104.5 & 106.1 & 79.6 & 116.6 & 104.9 & 107.0 & 109.0 & 111.7 & 121.4 & 141.3 \\
\hline 7122 & 19.9 & 48.0 & 40.8 & 18.0 & 13.2 & 14.6 & 23.4 & 16.3 & 28.3 & 29.3 \\
\hline 7131 & 58.1 & 53.7 & 25.8 & 26.6 & 35.4 & 49.0 & 40.2 & 53.4 & 82.1 & 75.6 \\
\hline 7132 & 41.5 & 41.6 & 42.3 & 44.0 & 49.0 & 48.9 & 48.9 & 56.6 & 55.2 & 67.9 \\
\hline 7133 & 202.8 & 67.8 & 151.1 & 189.5 & 101.3 & 69.8 & 100.8 & 91.0 & 132.5 & 151.9 \\
\hline 7134 & 52.8 & 53.9 & 49.8 & 54.6 & 59.2 & 57.3 & 55.3 & 52.1 & 57.8 & 73.0 \\
\hline 7140 & 24.7 & 26.8 & 26.1 & 31.7 & 35.6 & 30.3 & 30.4 & 33.1 & 26.2 & 25.2 \\
\hline 7210 & 43.0 & 31.2 & 28.4 & 40.6 & 26.7 & 47.0 & 66.7 & 53.0 & 59.5 & 57.6 \\
\hline 7220 & 52.4 & 49.0 & 50.6 & 49.7 & 53.7 & 54.5 & 57.6 & 67.7 & 66.4 & 74.9 \\
\hline $7221^{* * * *}$ & ** & ** & ** & ** & ** & 58.6 & 57.7 & 48.6 & 40.3 & 63.3 \\
\hline $7222^{* * * *}$ & ** & ** & ** & ** & ** & 54.3 & 57.6 & 68.4 & 67.1 & 75.2 \\
\hline $72.3 / 72.4$ & 55.4 & 65.8 & 55.2 & 54.6 & 54.4 & 51.1 & 56.3 & 51.3 & 58.1 & 71.9 \\
\hline 7250 & 26.9 & 35.9 & 36.0 & 44.5 & 39.9 & 38.2 & 41.5 & 44.1 & 38.9 & 23.0 \\
\hline 7260 & 28.6 & 36.0 & 29.2 & 36.4 & 44.4 & 43.3 & 51.3 & 52.3 & 57.5 & 65.2 \\
\hline 7411 & 36.0 & 37.9 & 43.5 & 45.7 & 45.9 & 47.0 & 49.6 & 53.7 & 59.0 & 59.0 \\
\hline 7412 & 38.6 & 38.4 & 39.3 & 44.3 & 44.9 & 45.7 & 44.6 & 48.0 & 57.9 & 55.5 \\
\hline 7413 & 19.6 & 25.0 & 25.6 & 23.6 & 24.6 & 22.9 & 31.5 & 25.6 & 33.1 & 30.4 \\
\hline 7414 & 49.5 & 49.1 & 53.8 & 46.2 & 42.3 & 47.1 & 46.6 & 52.9 & 56.0 & 63.8 \\
\hline 7415 & 69.1 & 29.0 & 37.8 & 51.0 & 43.2 & 15.1 & 18.3 & 2.7 & 8.0 & 12.5 \\
\hline 7420 & 39.5 & 37.9 & 40.6 & 41.7 & 38.3 & 46.4 & 45.8 & 50.2 & 50.6 & 55.1 \\
\hline 7430 & 29.5 & 29.7 & 30.1 & 28.7 & 31.7 & 44.3 & 45.2 & 39.7 & 53.6 & 42.7 \\
\hline 7440 & 39.2 & 61.3 & 62.6 & 53.8 & 56.4 & 60.7 & 53.9 & 75.7 & 63.3 & 67.7 \\
\hline 7450 & 17.6 & 19.4 & 22.2 & 20.1 & 21.7 & 22.2 & 24.1 & 24.7 & 27.2 & 28.4 \\
\hline 7460 & 14.1 & 15.6 & 17.2 & 17.4 & 20.0 & 19.7 & 20.8 & 23.7 & 25.3 & 27.2 \\
\hline 7470 & 6.0 & 6.5 & 6.8 & 7.8 & 8.5 & 9.5 & 9.7 & 9.8 & 9.8 & 11.9 \\
\hline 7481 & 19.6 & 23.1 & 27.9 & 21.9 & 22.3 & 24.8 & 31.6 & 32.1 & 33.5 & 29.0 \\
\hline 7482 & 20.8 & 22.1 & 20.1 & 25.8 & 29.7 & 23.9 & 36.3 & 32.3 & 40.1 & 46.3 \\
\hline $7485^{* * *}$ & 23.8 & 29.1 & 22.1 & 27.5 & 25.6 & 29.3 & 37.5 & 34.7 & 32.1 & 29.5 \\
\hline $7486^{* \star * *}$ & $* *$ & $* *$ & ** & $* *$ & $* *$ & 21.5 & 16.4 & 18.3 & 16.2 & 21.4 \\
\hline $7487^{\star * *}$ & 35.7 & 37.3 & 42.7 & 37.3 & 35.2 & 36.9 & 42.0 & 42.5 & 44.2 & 43.7 \\
\hline \multicolumn{11}{|c|}{ Other services } \\
\hline 9000 & 66.0 & 74.7 & 62.8 & 56.2 & 82.1 & 76.3 & 75.4 & 89.9 & 105.2 & 96.5 \\
\hline $9001^{* * * *}$ & $* *$ & ** & ** & ** & ** & 182.8 & 165.7 & 200.7 & 233.1 & 200.4 \\
\hline $9002^{* * * *}$ & $* *$ & ** & ** & ** & ** & 37.7 & 41.3 & 48.6 & 60.5 & 56.6 \\
\hline $9003^{* * * *}$ & $* *$ & $* *$ & ** & ** & $* *$ & 48.7 & 39.9 & 46.7 & 62.0 & 48.9 \\
\hline 9111 & 30.0 & 26.6 & 27.1 & 26.6 & 33.6 & 25.1 & 35.1 & 30.4 & 29.7 & 49.7 \\
\hline 9112 & 25.0 & 21.9 & 21.4 & 17.5 & 19.9 & 23.7 & 26.4 & 36.8 & 41.5 & 34.1 \\
\hline 9120 & 32.0 & 32.0 & 28.9 & 30.6 & 38.2 & 28.2 & 33.0 & 35.8 & 41.7 & 42.0 \\
\hline 9131 & -1.4 & -4.7 & -4.4 & -6.5 & -7.6 & -4.1 & -6.0 & -6.6 & -3.1 & -4.8 \\
\hline 9132 & 2.7 & * & -3.2 & -2.8 & -1.4 & -1.3 & -1.0 & -4.6 & -0.2 & 0.3 \\
\hline 9133 & 10.1 & 11.3 & 8.9 & 8.8 & 8.3 & 8.0 & 9.5 & 11.4 & 15.4 & 13.9 \\
\hline 9211 & 28.9 & 56.9 & 50.5 & 28.0 & 25.8 & 48.4 & 36.0 & 40.0 & 78.7 & 42.5 \\
\hline 9212 & 108.0 & 75.9 & 106.4 & 169.4 & 123.9 & 143.6 & 126.2 & 172.4 & 255.6 & 150.2 \\
\hline 9213 & 18.8 & 17.2 & 21.6 & 20.3 & 28.4 & 34.6 & 29.7 & 30.2 & 24.6 & 23.8 \\
\hline 9220 & 65.6 & 66.2 & 78.7 & 88.6 & 90.5 & 81.6 & 96.1 & 66.6 & 21.3 & 26.1 \\
\hline 9231 & 33.9 & 34.8 & 32.7 & 32.7 & 35.2 & 38.8 & 41.0 & 34.7 & 35.0 & 49.6 \\
\hline 9232 & 19.9 & 17.4 & 15.9 & 12.6 & 16.4 & 21.1 & 21.0 & 24.1 & 17.8 & 20.3 \\
\hline 9233 & 29.6 & 24.7 & 32.1 & 35.1 & 41.3 & 42.0 & 38.1 & 40.8 & 22.7 & 22.0 \\
\hline 9234 & 37.1 & 25.3 & 21.4 & 31.4 & 48.5 & 24.6 & 31.1 & 26.7 & 31.8 & 39.0 \\
\hline 9240 & 61.3 & 66.8 & 73.3 & 103.3 & * & 44.8 & 54.9 & 77.9 & 86.1 & 106.3 \\
\hline 9253 & 10.7 & 14.1 & 5.8 & 8.5 & 8.4 & 8.0 & 9.6 & 8.9 & 10.8 & 14.0 \\
\hline 9261 & 11.1 & 8.7 & 9.8 & 10.1 & 9.8 & 11.5 & 11.4 & 12.4 & 13.7 & 17.2 \\
\hline 9262 & 13.9 & 17.3 & 16.8 & 18.9 & 20.4 & 22.7 & 20.6 & 23.5 & 23.9 & 24.2 \\
\hline 9271 & 24.1 & 30.1 & 29.8 & 26.5 & 34.4 & 30.5 & 36.4 & 40.2 & 37.8 & 44.5 \\
\hline 9272 & 11.3 & 11.5 & 10.6 & 14.0 & 13.1 & 13.5 & 14.4 & 13.7 & 16.7 & 9.5 \\
\hline 9301 & 14.9 & 15.8 & 20.2 & 18.2 & 19.6 & 17.6 & 15.9 & 17.6 & 21.2 & 21.0 \\
\hline 9302 & 10.2 & 11.4 & 12.7 & 13.9 & 12.3 & 11.7 & 13.9 & 13.7 & 15.1 & 15.2 \\
\hline 9303 & 19.6 & 24.7 & 22.5 & 30.8 & 28.5 & 29.9 & 32.7 & 28.0 & 26.8 & 28.7 \\
\hline 9304 & 18.7 & 17.8 & 24.8 & 25.1 & 20.2 & 22.6 & 16.4 & 18.4 & 26.7 & 21.4 \\
\hline 9305 & 20.5 & 23.9 & 24.9 & 27.4 & 24.7 & 29.7 & 33.0 & 37.9 & 35.2 & 31.5 \\
\hline
\end{tabular}

\section{Notes:}

$1 \quad$ Excluding SIC Divisions 12, 13, 40, 65-67, 70, 73 and 75-85.

Source: Office for National Statistics

$* * * *$ SIC discontinued from 2003.

$* * * * \quad$ New SIC from 2003.

*** Change of industry classification from SIC92 to SIC03 - pre-2003 data have been assigned to the new classification.

** Not available.

* Information suppressed to avoid disclosure or because employment estimate is less than 500 . 